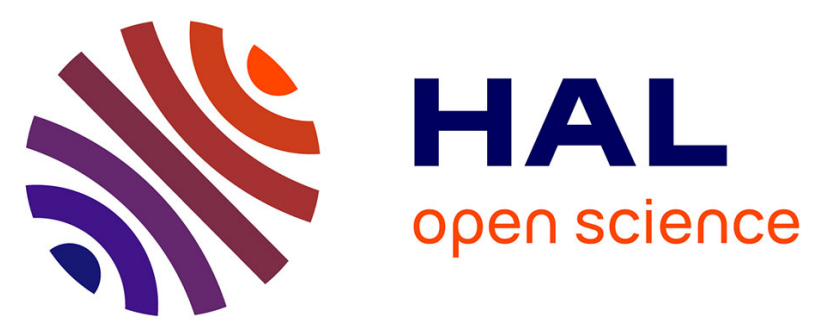

\title{
Study of a photocatalytic process for removal of antibiotics from wastewater in a falling film photoreactor: Scavenger study and process intensification feasibility
}

\author{
W. Lou, A. Kane, D. Wolbert, S. Rtimi, A.A. Assadi
}

\section{To cite this version:}

W. Lou, A. Kane, D. Wolbert, S. Rtimi, A.A. Assadi. Study of a photocatalytic process for removal of antibiotics from wastewater in a falling film photoreactor: Scavenger study and process intensification feasibility. Chemical Engineering and Processing: Process Intensification, 2017, 122, pp.213-221. 10.1016/j.cep.2017.10.010 . hal-01671634

HAL Id: hal-01671634

https://hal-univ-rennes1.archives-ouvertes.fr/hal-01671634

Submitted on 1 Feb 2018

HAL is a multi-disciplinary open access archive for the deposit and dissemination of scientific research documents, whether they are published or not. The documents may come from teaching and research institutions in France or abroad, or from public or private research centers.
L'archive ouverte pluridisciplinaire HAL, est destinée au dépôt et à la diffusion de documents scientifiques de niveau recherche, publiés ou non, émanant des établissements d'enseignement et de recherche français ou étrangers, des laboratoires publics ou privés. 


\title{
Study of a photocatalytic process for removal of antibiotics from wastewater in
}

\section{a falling film photoreactor: scavenger study and process intensification}

\author{
feasibility
}

Wanruo LOU ${ }^{a}$, Abdoulaye KANE ${ }^{b}$, Dominique WOLBERT' ${ }^{c}$, Sami RTIMI ${ }^{d}$, Aymen Amine ASSADI ${ }^{*}$

\begin{abstract}
${ }^{a}$ Ecole Nationale Supérieure des Industries Chimiques (ENSIC), 1 rue Grandville BP 20451 Nancy cedex, France
${ }^{b}$ Ecole des Métiers de l'Environnement (EME), Campus de Ker Lann, avenue Robert Schuman Bruz, France

${ }^{\mathrm{c}}$ Ecole Nationale Supérieure de Chimie de Rennes (ENSCR), CNRS, UMR 6226, 11 allée de Beaulieu, CS 50837,35708 Rennes Cedex 7, France

${ }^{d}$ Ecole Polytechnique Fédérale de Lausanne, EPFL-STI-LTP, Station 12, CH-1015 Lausanne, Switzerland.
\end{abstract}

* Corresponding author. Tel.: +33(0)223238152; Fax: +33 (0)299058809

E-mail addresse: aymen.assadi@ensc-rennes.fr (A. ASSADI)

Graphical Abstract

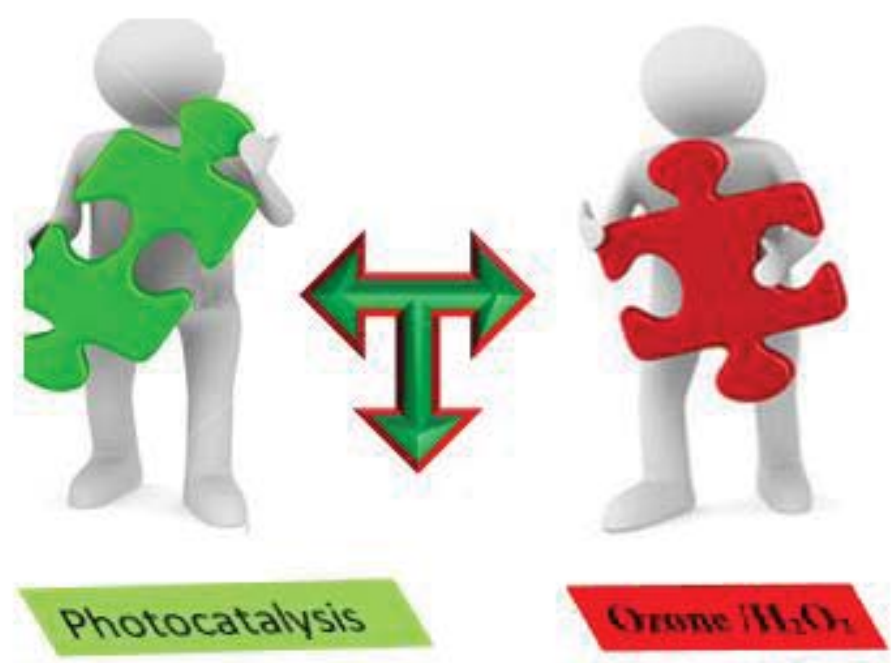

Combined of ozone/ $\mathrm{H}_{2} \mathrm{O}_{2}$ with a falling film photoreactor

Highlights

- Effect of several operating parameter on photocatalytic process were investigated

- A plausible removal pathway of flumequine in $\mathrm{TiO}_{2} / \mathrm{UV}$ system was proposed

- Photocatalytic removal of a mixture of antibiotics in wastewater was studied

- Removal efficiency is improved when adding $\mathrm{CCl}_{4}$

- Intensification of photocatalytic activity was investigated with adding $\mathrm{O}_{3}$ and $\mathrm{H}_{2} \mathrm{O}_{2}$ 


\section{Abstract}

This study focused on the removal of antibiotic by coupling of heterogeneous photocatalysis with ozonation and hydrogen peroxide. The main objective was to intensify the efficiency of photocatalytic activity for better and faster antibiotic elimination/mineralization in wastewater. To fulfill this purpose a photocatalytic process based on falling film reactor was designed and optimized. The effects of operating parameters such as wastewater flow rate in the falling film reactor, the presence of an oxidizing agent $\left(\mathrm{H}_{2} \mathrm{O}_{2}\right.$ and $\left.\mathrm{O}_{3}\right)$, inlet concentrations, including catalyst dosage and light intensity were investigated and discussed. Experiments were mainly conducted with Flumequine and Clarithromycin. The first molecule (Flumequine) will serve as an example of fluoroquinolone antibiotics and the second (Clarithromycin) as an example of macrolide antibiotics. Experimentally, the results have shown interesting degradation and mineralization efficiency (on the order of $94 \%$ for degradation and $76 \%$ for mineralization). Evidence for redox catalysis was shown using X-ray photoelectron spectroscopy (XPS) before and after pollutant degradation. Moreover, special attention was also paid to identify the reaction products and the plausible degradation pathway during Flumequine degradation.

Keywords: Advanced Oxidation Processes; Antibiotic; Process Intensification; Mass transfer; Redox catalysis; Scavengers;

\section{Introduction}

An antibiotic is a natural or synthetic substance that destroys or inhibits the growth of microbes. Since their discovery in 1943, thousands of antibiotics have been used/reported. The widespread introduction of antibiotics was one of the most important therapeutic advances of the twentieth century [1]. Antibiotics have helped to extend expected life spans by reducing the consequence of bacterial infections [2]. Antibiotics are physiologically active substances used in livestock farms to suppress parasites, prevent diseases, and increase productivity [3]. However, the antibiotics used for animals cannot be completely absorbed or metabolized in vivo. It means that approximately $30-90 \%$ of the administered antibiotics are being excreted through urine and feces, and subsequently released into the surrounding ecosystem [4]. Due 
to the biological activation longevity, the released antibiotics lead to serious environmental degradations and cause risks to human health $[5,6]$.

In this study we investigate the $\mathrm{TiO}_{2}$ based photocatalytic decomposition of two antibiotics (Flumequine and Clarithromycin), chosen among those most largely used for human and veterinary treatment.

Nowadays, fluoroquinonoles are some of the most concentrated active principles encountered in wastewater effluents [7]; among them Flumequine is the most commonly used [8] to treat bacterial infections in veterinary medicine for preventive or curative treatment for salmon and trout. Some studies reported concentrations ranging from 2.5-50 ng/L [9-11].

Clarithromycin belongs to the category of pharmaceuticals called macrolides and is a recurring pollutant encountered in the environment. Clarithromycin residues have been detected in wastewater (100-319 ng/L) [12,13], in Waste Water Treatment Plant effluent (99-280 ng/L) $[13,14]$, and in surface water (6-88 ng/L) [14,15]. Siemens et al. [16] demonstrated an average concentration of $0.39 \mu \mathrm{g} / \mathrm{L}$ of Clarithromycin in the wastewater in Mexico, and similar concentrations were reported for sewage in Europe, Japan, and the USA $[17,18]$. Clarithromycin is very difficult to break down when it reaches the environment. The presence of these drugs in water and soil has attracted the attention and concern of the worldwide scientific community.

Most conventional wastewater treatment plants are not efficient to remove antibiotics from wastewaters. Therefore, more practical and economical processes must be developed in order to reduce the antibiotic discharges into the environment. Physicochemical methods such as membrane filtration [18] and adsorption using activated carbon [19] have been applied to treat micropollutants e.g. antibiotics. However, the main disadvantage of such methods is that they do not destroy the pollutants but transfer the pollutant from one phase to another [20]. Nowadays, advanced oxidation processes (AOP) have been proposed as alternative methods for the elimination of antibiotics among other compounds in wastewater [21]. The principle of advanced oxidation processes (including $\mathrm{O}_{3} / \mathrm{H}_{2} \mathrm{O}_{2}, \mathrm{UV} / \mathrm{O}_{3}, \mathrm{UV} / \mathrm{H}_{2} \mathrm{O}_{2}, \mathrm{H}_{2} \mathrm{O}_{2} / \mathrm{Fe}^{2+}$, and UV- $-\mathrm{TiO}_{2}$ ) 
is to produce hydroxyl radicals $\left({ }^{\circ} \mathrm{OH}\right)$ in water, a very powerful oxidant $\left(\mathrm{E}^{\circ}=2.8 \mathrm{~V}\right)$ capable of oxidizing a wide range of organic compounds with one or many double bonds [22]. Hydroxyl radicals are produced by oxidizing agents such as ozone, or hydrogen peroxide, and often enhanced with appropriate light radiation of semiconductor/metal oxides.

Clarithromycin and other macrolide antibiotics (e.g. azithromycin and erythromycin) have recently been included in the watch list of European Decision 2015/495/EU [23] as substances that should be monitored in order to generate the data on their occurrence in the aquatic environment and to confirm their risk which could lead to their inclusion in the priority substances list. Nevertheless, to our knowledge, there are currently no known regulations for Flumequine (one of the first generations of fluoroquinolone antibiotics) in terms of substances that should be monitored as it has been the case for Clarithromycin. This challenge involves using preferably selective techniques such as heterogeneous photocatalysis[24,25].

This latter technique has been well-known at the fundamental level in the literature, particularly with regards to degradation mechanisms [24]. However, various studies show that the overall reaction rate of photocatalytic processes for water treatment is usually slow compared to conventional chemical reaction rates $[26,27]$ due mainly to the low concentration level of pollutants. Likewise, photon transfer and mass transfer limitations should also be considered as part of heterogeneous photocatalysis constraints [25]. Hence, new ways must be explored to improve this aspect. One of the original features of this study is the implementation of falling film reactor by combining photocatalysis and other advanced oxidation processes (AOPs).

It is well established that advanced oxidation processes (AOPs) present interesting efficiencies for the elimination of persistent substances $[24,26,28-30]$. Photocatalytic processes are the most commonly used AOPs and have been successfully applied for the degradation of a wide range of antimicrobial agents in aqueous solutions [7,24,31,32]. The most commonly used semiconductor photocatalyst is $\mathrm{TiO}_{2}$ due to its low cost, high stability, and low environmental impact [24]. 
Recent studies have demonstrated the feasibility of Flumequine degradation in aqueous solutions $[8,33-36]$. Other studies have used photocatalysis to successfully degrade Flumequine [37-41]. Others have focused on the photocatalytic degradation of Clarithromycin and reported low degradation efficiencies [42-46].

In the present study we combine $\mathrm{UV} / \mathrm{TiO}_{2} / \mathrm{H}_{2} \mathrm{O}_{2} / \mathrm{O}_{3}$ for Flumequine and Clarithromycin degradation in water (degradation of Flumequine alone or in a mixture with Claritromycin). These two molecules represent two families of antibiotics (fluoroquinolone and macrolide) which are attracting more and more the attention of the authorities as well as the scientific community. The novelty of this work is also related to the evaluation of the possible effects of a wide range of operating parameters influencing the photocatalytic degradation of Flumequine and Claritromycin. In addition, the possible competitive interactions between antibiotics and the photocatalyst surface during the treatment were also studied by mixing Flumequine and Clarithromycin in various proportions. Consequently, we have especially studied the effect of radicals and hole scavengers in order to elucidate the pathways involved in the photocatalytic degradation of these antibiotics.

\section{Materials and methods}

\subsection{Chemical reagents}

Our study focuses on degradation of 2 selected drug models: Flumequine and Clarithromycin. Flumequine, as a first-generation fluoroquinolone antibacterial, could represent the characteristics of other fluoroquinolone antibiotics, because of a similar chemical structure. And Clarithromycin, as a macrolide antibiotic, has been commonly used over the years. In this study, the Flumequine (98\%) was purchased from Alfa Aesar. Clarithromycin was from Sigma Aldrich. Acetonitrile (quality of LC / MS) was purchased from Biosolve BV. $\mathrm{H}_{3} \mathrm{PO}_{4}$ and $\mathrm{KH}_{2} \mathrm{PO}_{4}$ were supplied from Carlo Erba. The deionized water was $18.2 \mathrm{M} \Omega \mathrm{cm}$ at $25^{\circ} \mathrm{C}$. 


\subsection{Analytical methods}

The concentration of Flumequine was measured by a UV-Vis spectrophotometer incorporating a Xenon flash lamp (Varian CARY UV50 Probe) at a wavelength of $246 \mathrm{~nm}$, while using 0.01 $\mathrm{m}$ cell path length quartz.

In case of mixtures of Flumequine and Clarithromycin, the two studied antibiotics were analyzed by a reversed-phase ultra-performance liquid chromatography (RP-UPLC). The mobile phase is an eluent $\mathrm{A}$ of a mixture of $\mathrm{KH}_{2} \mathrm{PO}_{4}$ and $\mathrm{H}_{3} \mathrm{PO}_{4}$ with $\mathrm{pH}=3$.2. It was selected as buffer solution while eluent B was acetonitrile. Organic solvents employed to prepare mobile phases were UPLC-grade. The aqueous $\mathrm{KH}_{2} \mathrm{PO}_{4}$ and $\mathrm{H}_{3} \mathrm{PO}_{4}$ solution was prepared as follows: Potassium phosphate monobasic $(9.11 \mathrm{~g})$ was dissolved in $1 \mathrm{~L}$ of water, and the $\mathrm{pH}$ was adjusted to 3.2 with $\mathrm{H}_{3} \mathrm{PO}_{4}$. Both $\mathrm{KH}_{2} \mathrm{PO}_{4}\left(99.5 \%\right.$,) and $\mathrm{H}_{3} \mathrm{PO}_{4}$ (>99.) are HPLC grade and from Sigma Aldrich. The flow rate was set at $0.4 \mathrm{~mL} / \mathrm{min}$.

The system consisted of a pump Waters (Quaternary solvent manager), an apolar column Waters BEH C18 (2.1 x 100mm), a UV detector diode array (Waters L10UPL 694A) for an analysis of $195-400 \mathrm{~nm}$.

The temperature of column and sample were $45^{\circ} \mathrm{C}$ and $5{ }^{\circ} \mathrm{C}$ respectively. The volume of injection was $10 \mu \mathrm{L}$.

The initial eluent composition was 30\% A / 70\% B for 1 min and then the proportion returned to initial conditions in $1 \mathrm{~min}$. This linear gradient could separate the two peaks via time.

The mineralization was controlled by a TOC analyzer (Shimadzu TOC-L CPH). The TOC-L series of TOC analyzers adopts the $680^{\circ} \mathrm{C}$ combustion catalytic oxidation method, while providing an ultra-wide range of $4 \mu \mathrm{g} / \mathrm{L}$ to $30 \mathrm{mg} / \mathrm{L}$, these analyzers boast a detection limit of $4 \mu \mathrm{g} / \mathrm{L}$.

\subsection{Catalyst and Experimental set-up}

\subsubsection{Redox catalysis as detected by X-ray photoelectron spectroscopy (XPS)}


The photocatalytic media provided by Ahlstrom Company, under reference Alhström 1048, is a non-woven textile composed of cellulose fibers coated with a mix of catalyst $\left(\mathrm{TiO}_{2}\right.$ Millennium PC 500), zeolite and silica. The layer catalyst thickness is equal to $250 \mu \mathrm{m}$.

The X-ray photoelectron spectroscopy (XPS) of the photocatalyst was determined using an AXIS NOVA photoelectron spectrometer (Kratos Analytical, Manchester, UK) provided for with monochromatic AlKa ( $\mathrm{hn}=1486.6 \mathrm{eV})$ anode. The carbon C1s line with position at $284.6 \mathrm{eV}$ was used as a reference to correct the charging effects. The surface atomic concentration was determined by XPS from the peak areas, using the known sensitivity factors for $\mathrm{Ti}$ and $\mathrm{O}$. The surface percentages composition was determined within the topmost atomic layers. The XPS spectral peaks were deconvoluted with a CasaXPS-Vision 2, Kratos Analytical UK.

\subsubsection{Experimental Set-Up}

The pilot used in this study consists of a pump, a spillway, a storage tank, a reactor with a staircase that was equipped with UV lamps and catalyst paper (Figure 1). It suits the term "falling film flow", which represents an alternating horizontal and vertical flow film. This system has several advantages:

- A thin water film on the catalyst, thus generating low absorption of UV light;

- The six steps of staircase could both increase the catalyst surface and improve oxygenation of the waste solution. Indeed, the geometry of this film allows a large exchange surface between the liquid and the air, thus increasing oxygen transfer in water.

The photoreactor $[47,48]$ was made of six regular steps of the same dimensions (depth/height/width: $6 \mathrm{~cm} / 6 \mathrm{~cm} / 25 \mathrm{~cm}$ ) covered with the photocatalytic media $\left(0.18 \mathrm{~m}^{2} ; 72\right.$ $\mathrm{cm} \times 25 \mathrm{~cm}$ corresponding approximately to $4 \mathrm{~g}$ of $\mathrm{TiO}_{2}$ ). Three UV lamps, Phillips PL-L24 $\mathrm{W} / 10 / 4 \mathrm{P}(\lambda \max =365 \mathrm{~nm})$ were placed at the inside of a cover. In a previous work [49], the radiant flux was measured by means of a chemical actinometer. Potassium ferrioxalate was used because its quantum yield remains quite constant between 250 and $400 \mathrm{~nm}$. Then the 
average irradiance value for one lamp was $14.5 \mathrm{~W} \cdot \mathrm{m}^{-2} ; 27 \mathrm{~W} \cdot \mathrm{m}^{-2}$ for two lamps and $38 \mathrm{~W} \cdot \mathrm{m}^{-2}$ for three lamps.

As a first step, the solution was introduced in a tank equipped with a magnetic stirrer and was pumped with a flow rate ranging from 70 to $150 \mathrm{l} / \mathrm{h}$. The liquid flow on the photocatalytic surface was in the form of a thin falling film.

For most of the experiments, $2 \mathrm{~L}$ of various concentrations of a neutral polluted solution were used. In the case of coupling ozone and $\mathrm{H}_{2} \mathrm{O}_{2}$ with photocatalysis experiment, $3 \mathrm{~L}$ of solution were prepared in order to ensure a sufficient liquid volume for the passage of ozone. The solution was added from the storage tank, and cycled by the pump. Samples were taken from the tank to evaluate the antibiotic concentration versus time.

After reaching adsorption/desorption equilibrium after 30 minutes in the dark, the photocatalytic degradation began with the UV lamps turned on to irradiate the solution.

\section{Insert Fig.1, here}

\section{Results and discussion}

\subsection{Effect of initial concentration on the removal rate of Flumequine}

Figure 2 shows the variation of initial reaction rate versus initial concentration. As seen, reactant concentration influences the reaction rate, the initial concentration affects the adsorbed polluant concentration in the surface of $\mathrm{TiO}_{2}$ catalyst. As a result, when the concentration in the solution is low, the mass transfer is limited. Since the initial Flumequine concentration is high, mass transfer is not a constraint, thus the reaction rate is higher due to limitation of active sites (Figure 2). This resultat is similar to that seen in the works of Brosillon et al., on photocatalytic removal of persticids [49].

\section{Insert Fig.2, here}




\subsection{Effect of Flow Rate}

Mass transfer limitations become a dominant factor when using an immobilized $\mathrm{TiO}_{2}$ layer, which usually lead to a lower overall degradation rate [50].

Compared to suspended catalyst systems, research has been carried out on $\mathrm{TiO}_{2}$ immobilization. On the basis of the research of Ajay K. Ray, 2016[51], there are two obvious problems arising from this arrangement: one is the accessibility of the catalytic surface to the photons and the reactants, and another is a significant influence of the external mass transfer resistance particularly at low fluid flow rates, due to the increasing diffusion length of the reactant from the solution to the catalyst surface.

So it's obvious that flow rate plays a crucial role in the degradation process. In a specific experiment, we settled on a flow rate which ranged from 70 to $150 \mathrm{~L} / \mathrm{h}$.

Figure 3 shows the evolution of Flumequine reaction rate with flow rate and also confirms the observations drawn above.

\section{Insert Fig. 3, here}

Here, we note that for low flow rates, Flumequine is highly degraded. However, when the flow rate is above $149 \mathrm{~L} / \mathrm{h}$, we see another trend. In fact, at high value flow rates, the photocatalytic removal of Flumequine is inhibited. Therefore the following explanation was proposed:

- For low flow rates, the water film is thin; oxygen is much more able to come into contact with a catalytic surface. Furthermore, a thin water film contributes to satisfactory light intensity.

- When the flow rate is above $149 \mathrm{~L} / \mathrm{h}$, we get another approving apparent kinetic constant. While increasing the flow rate of the thickness of water film increases, which has the disadvantage of photon entering into the interface of two phases. However, increasing the flow rate also leads to a good mass transfer. Even more, with good mass transfer (due to the equivalent of self- stirring for each step) and hole/electron recombination there was an increase of pollutant degradation. 
Using the same experimental set-up, Brosillon et al [49] have proved that the maximum Reynolds number $\mathrm{Re}_{\max }$ was equal to 265 , and confirming that the flow was laminar for the flow rate range studied.

It is important to note that in the falling film photoreactor, there is recirculation between the tank and the irradiation zone (reaction zone). As such, the complete setup could be regarded as a mixed batch reactor.

In order to better understand the effect of flow rate on process performance, the model of Langmuir Hinshelwood (L-H) was used. Indeed, for example, the selected figures in the beginning period of degradation at $77 \mathrm{~L} / \mathrm{h}$ (30min, 35min, 40min, 45min, and 50min) were used to plot a regression line (on the linear part of the curve) and obtained slope represents the initial degradation rate (eq.1):

$$
r=-\frac{d C}{d t}
$$

After the 4 experiments with initial concentration $C_{0}(10 \mathrm{mg} / \mathrm{L}, 20 \mathrm{mg} / \mathrm{L}, 30 \mathrm{mg} / \mathrm{l}$, and $40 \mathrm{mg} / \mathrm{L})$, we drew a liner of $\frac{1}{\mathrm{r}}$ and $\frac{1}{\mathrm{co}}$. By means of linearization for Langmuir-Hinshelwood Isotherm, we obtained the relation (eq.2):

$$
\frac{1}{r}=\frac{1}{k K C}+\frac{1}{k}
$$

When setting one of these flow rates $(77.0 \mathrm{~L} / \mathrm{h}, 87.8 \mathrm{~L} / \mathrm{h}, 113.7 \mathrm{~L} / \mathrm{h}, 149.0 \mathrm{~L} / \mathrm{h})$, we changed the initial concentration of $C_{0}(10,20,3040 \mathrm{mg} / \mathrm{L})$, thereby we can get the values of $\mathrm{k}$ (apparent kinetic constant) and $\mathrm{K}$ (equilibrium constant) for each specific flow rate.

Obtained $k$ values (apparent kinetic constant) at different flow rates are summarized in Table 1. There was a clear "non-linear" relation between $\mathrm{k}$ and the flow-rate.

Insert Table 1, here 
To better underpin the relation between reaction rate and flow rate, it was considered necessary to evaluate the value of film thickness which can be calculated by this relation [49]:

$$
\text { Thickness }=\left(\Gamma^{2} / g\right)^{1 / 3} \text { with } \quad \Gamma=\frac{Q}{L}
$$

where $\Gamma$ is the flow per unit of width $\left(\mathrm{m}^{3} \cdot \mathrm{s}^{-1} \cdot \mathrm{m}^{-1}\right), \mathrm{L}=$ is the depth of the step, $\mathrm{Q}$ is the flow rate and $g$ the gravity.

The falling film thicknesses values are summarized in Table 2 and range from 0.9 to $1.4 \mathrm{~mm}$ depending to flow rate. With regard to these values of falling film thickness (about $1 \mathrm{~mm}$ ), one can expect improved selectivities and an increase in overall conversion since the film thickness is a parameter that is relevant in the photon absorption models [52,53].

\section{Insert Table 2, here}

With respect to the study of Behnaz Sheidaei, 2015 [54], kapp (apparent rate constant) increases with increasing volumetric flow rate under the continuous-flow ambiance. Besides, the enhancement of $k_{a p p}$ with increasing volumetric flow rate of liquid may be related to the higher amount of liquid passing through the photoreactor and an increase in the mass transfer rate[55].

Serpone et al. [28] demonstrated that in multipass mode experiments, both reactors exhibit higher degradation rates for phenol at higher flow rates. By contrast, greater degradation is associated with lower flow rates in single-pass mode experiments, which tells us that the effects of flow rate also depend on the different reactors.

\subsection{Effect of UV light intensity}

To assess the influence of UV intensity on the degradation and mineralization of Flumequine, several experiments at different inlet concentrations and different UV intensities were performed with Flumequine on the photocatalytic reactor. Different light intensities were obtained by varying the number of lamps (one lamp emitted a UV intensity of $14.5 \mathrm{~W} \cdot \mathrm{m}^{-2}$; two 
lamps: $27 \mathrm{~W} \cdot \mathrm{m}^{-2}$; three Lamps: $38 \mathrm{~W} \cdot \mathrm{m}^{-2}$ ). Here, the flow rate and the value of $\mathrm{pH}$ were kept constant at $77 \mathrm{~L} / \mathrm{h}$ and 6.6 respectively.

Admittedly, light intensity is an elementary factor in antibiotic degradation, because electronhole pairs are produced by UV light energy. Table 3 and Fig. 4 show a rise in the degradation rate constant $\mathrm{k}_{\mathrm{app}}$ of Flumequine with increased light intensity for a certain initial concentration. For example, the decomposition rate at $38 \mathrm{~W} / \mathrm{m}^{2}$ is faster than at 27 and $14.5 \mathrm{~W} / \mathrm{m}^{2}$. This is because a higher light intensity provides higher energy for more $\mathrm{TiO}_{2}$ to produce electron-hole pairs. Additionally, it is evidently observed that $\mathrm{k}_{\mathrm{app}}$ increases by increasing light intensity.

\section{Insert Table 3, here}

\section{Insert Fig. 4, here}

Fig 4. shows the influence of the UV light intensity on degradation rate, the following model [56] was used to represent this behavior:

$$
\mathrm{r}=\mathrm{k}_{\mathrm{app}}{ }^{*}(\mathrm{I})^{\alpha} \quad(4)[56]
$$

With a low UV intensity light, the value of $\alpha$ approximately equal to 1 , the degradation rate presented a first order reaction [57][56]. As the UV intensity light increased, the reaction degree decreased. Thus, the kinetic constant is plotted versus the light intensity on a log-log scale (Fig.4). As seen, the degradation rate of Flumequine increased with UV light, following a firstorder regime. This result shows a nearly linear correlation between the UV light intensity and kinetic constant of Flumequine degradation. Thus the experiments were not performed under UV saturation and, therefore, the consummation of the electron-hole pairs was more rapidly by chemical reactions than by recombination[56].

\subsection{Photocatalyst poisoning}

When the quantity of lamps was reduced, the immobile $\mathrm{TiO}_{2}$ paper changed to a much more yellow color.. Higher UV light intensity provides higher energy for more $\mathrm{TiO}_{2}$ to produce 
electron-hole pairs. During the Flumequine degradation, the shortfall of hole/electron when light was lacking would cause catalyst poisoning, which contributed to the color change (yellowish color).

After regeneration under 3 UV lamps and stirring the water for about $1 \mathrm{~h}$, the color returned to white from yellow.

\subsection{Competition effect: case of mixture of Flumequine and Clarithromycin}

The molar mass of Flumequine and Clarithromycin are $261.25 \mathrm{~g} / \mathrm{mol}$ and $747.953 \mathrm{~g} / \mathrm{mol}$ respectively. Molecules of Flumequine and Clarithromycin have 14 and 38 atoms of carbon, respectively .We try to degrade a wastewater model containing a mixture of Flumequine and Clarithromycin. While mixing the Flumequine and Clarithromycin by the molar ratio of 50\%:50\%, the concentration changed as shown in Fig 5 .

\section{Insert Fig. 5, here}

It is worth pointing out that in figure 5 both the phenomena of adsorption and photocatalysis were observed. The solution was stirred in the dark for 30 minutes in order to reach Flumequine and/or Claritromycin absorption-desorption equilibrium, which will allow for the commencement of the photocatalytic reaction (after 30 minutes).

Concomitant with the adsorption equilibrium, Flumequine concentration drastically decreased, while the concentration of Clarithromycin decreased slightly. Furthermore, Clarithromycin continue to decline even when the majority of Flumequine was eliminated.

We obtained different values of reaction rates for these two organic compounds by changing the molar ratio of Clarithromycin from $30 \%, 50 \%$ to $70 \%$. Fig 6 shows the evolution of the reaction rate for different Clarithromycin molar ratios. The selectivity of Flumequine degradation went down along with rising molar ratio of Clarithromycin.

Insert Fig. 6, here 


\subsection{Effect of different radical scavengers}

Admittedly, electron-hole pairs $(e / h+)$ on the surface of $\mathrm{TiO}_{2}$ are produced by absorbing UV photons[58]. Amruta Shet et al. 2015 [59] have proved that an electron-hole recombination leading to a lower rate of photocatalysis is a disadvantage of $\mathrm{TiO}_{2}$. The degradation efficiency is governed by the capability to overcome electron-hole recombination limitations. Y. Nakabayashi, $\mathrm{Y}$ et al., 2013 [60] presented that water and $\mathrm{O}_{2}$ could transfer electrons from $\mathrm{TiO}_{2}$, then holes from a valence band could produce ${ }^{\circ} \mathrm{OH}$. The produced ${ }^{\circ} \mathrm{OH}$ could attack Flumequine.

We investigated three different radical scavengers EDTA, iso-propanol and carbon tetrachloride $\left(\mathrm{CCl}_{4}\right)$ to add into wastewater. Some recent experiments were conducted to prove that EDTA and iso-propanol were hole scavengers, while $\mathrm{CCl}_{4}$ was an electron scavenger. These mechanisms are described in table 4 [61].

\section{Insert Table. 4, here}

Table 5 shows the effect of different radical scavengers on both removal efficiency and mineralization of Flumequine after $300 \mathrm{~min}$ of reaction (for $\mathrm{C}_{0}=30 \mathrm{mg} / \mathrm{L}$ ).

\section{Insert Table 5, here}

The results of degradation and mineralization will be pointed out to better understand the pathway of flumiquine degradation and to study the contribution of hydroxyl radicals in the reaction mechanism.

The effect of adding radical scavengers (such as EDTA) during Flumequine degradation process was investigated. When Flumequine solution was added to $200 \mathrm{mg} / \mathrm{L}$ EDTA, a reduction of Flumequine degradation efficiency from $95 \%$ to $75 \%$ was observed, which translates into a sharp decrease from $86 \%$ to $40 \%$ of TOC efficiency (Table 5 ), this behavior is mainly due to the inhibition of the activity of the photo-generated holes. 
In the presence of $2.00 \mathrm{~mL} / \mathrm{L}$ iso-propanol, the mineralization efficiency of organic compounds slightly dropped from $86 \%$ to $83 \%$.

By contrast, by adding $0.1 \mathrm{~mL}$ of $\mathrm{CCl}_{4}$, the mineralization efficiency of Flumequine was improved from $86 \%$ to $91 \%$, which reduced the chance of recombination of $\bullet \mathrm{H}$ and $\bullet \mathrm{OH}$ and finally led to the increase of the degradation efficiency of Flumequine.

\subsection{Process intensification: case of coupling Ozone and $\mathrm{H}_{2} \mathrm{O}_{2}$ with photocatalysis}

The investigation scavenger shows that ${ }^{\circ} \mathrm{OH}$ radicals are the main active species in the falling film photocatalytic reactor. In order to enhance the amount of active species, we added $\mathrm{H}_{2} \mathrm{O}_{2}$ and $\mathrm{O}_{3}$ as oxidant agents.

After the 30 min required ensuring the adsorption equilibrium between Flumequine and the $\mathrm{TiO}_{2}$ surface, the UV light was switched on and simultaneously $\mathrm{H}_{2} \mathrm{O}_{2}$ was added. Fig 7 shows the adsorption phenomenon during the first $30 \mathrm{~min}$, then, the concentration of Flumequine reached a steady value regardless of these different 4 systems in the figure.

With the addition of $\mathrm{H}_{2} \mathrm{O}_{2}$, the adsorption-desorption equilibrium was broken; the Flumequine concentration in the water was suddenly increasing even if the photocatalytic degradation process had already begun.

This can be attributed to the fact that the added $\mathrm{H}_{2} \mathrm{O}_{2}$ was first adsorbed on the $\mathrm{TiO}_{2}$ surface, which contributed to a quantity of Flumequine desorption, thereby the detected Flumequine concentration increased in a short time slot. Beltran et al. argued that dissolved ozone is first adsorbed onto $\mathrm{TiO}_{2}$ surface in $\mathrm{TiO}_{2}$-catalyzed ozonation processes [30]. After 2 hours, the Flumequine concentration decreased much more quickly due to the presence of $\mathrm{H}_{2} \mathrm{O}_{2}$. Figure 7 therefore demonstrated that only the adsorbed $\mathrm{H}_{2} \mathrm{O}_{2}$ could react with the adsorbed organic compound on the $\mathrm{TiO}_{2}$-active site.

The efficiency of the Flumequine mineralization in Fig 8 showed that $2 \mathrm{mmol} / \mathrm{L} \mathrm{H}_{2} \mathrm{O}_{2}$ was the optimal concentration in the $\mathrm{TIO}_{2} / \mathrm{UV} / \mathrm{H}_{2} \mathrm{O}_{2}$ system, which was better than others. 


\section{Insert Fig. 7, here}

Flumequine mineralization was followed by TOC determination; Fig.8 shows mineralization in the absence or presence of hydrogen peroxide. Different concentrations of $\mathrm{H}_{2} \mathrm{O}_{2}$ were tested within the mineralization time. After rising sharply during the first 30 minutes $(60 \%$ mineralization for Flumequine after 30 min irradiation with $2 \mathrm{mmol} / \mathrm{L}$ of $\mathrm{H}_{2} \mathrm{O}_{2}$ ) mineralization evolved slightly.

\section{Insert Fig. 8, here}

The processes of degradation and mineralization of Flumequine including ozonation were also investigated. The tested systems included: $\mathrm{UV} / \mathrm{O}_{3}, \mathrm{TiO}_{2} / \mathrm{O}_{3}, \mathrm{TiO}_{2} / \mathrm{UV}, \mathrm{TiO}_{2} / \mathrm{UV} / \mathrm{O}_{3}, \mathrm{TiO}_{2} / \mathrm{UV} /$ $\mathrm{H}_{2} \mathrm{O}_{2} / \mathrm{O}_{3}$. The obtained results are summarized in Table 6.

Table 6 shows that among the investigated AOPs systems, the combination of oxidation with $\mathrm{H}_{2} \mathrm{O}_{2}$ and $\mathrm{O}_{3}$, of photocatalysis with $\mathrm{TiO}_{2}$ and UV light in wastewater treatment presented the best efficiency for Flumequine degradation as shown in Table 6.

The $\mathrm{TiO}_{2} / \mathrm{H}_{2} \mathrm{O}_{2} / \mathrm{UV}$ process is much more effective than the $\mathrm{TiO}_{2} / \mathrm{O}_{3} / \mathrm{UV}$-radiation process for Flumequine mineralization. Furthermore, it can be concluded that regardless of the combination of $\mathrm{H}_{2} \mathrm{O}_{2}$ or $\mathrm{O}_{3}$, they were better than the photocatalysis $\mathrm{TiO}_{2} / \mathrm{UV}$ condition because of contribution of $\cdot \mathrm{OH}, \cdot \mathrm{O}^{-}$and $\cdot \mathrm{O}^{2-}$.

By comparing the $\mathrm{TiO}_{2} / \mathrm{O}_{3}$ and the $\mathrm{TiO}_{2} / \mathrm{UV}$ processes, Table 6 shows that UV light provides the required energy for $\bullet \mathrm{OH}$ radical producing, thereby for the mineralization of organic compounds. In addition, by comparing the $\mathrm{UV} / \mathrm{O}_{3}$ and $\mathrm{TiO}_{2} / \mathrm{UV}$ processes, we can conclude that the photocatalytic process degraded Flumequine much more effectively than the photooxidation process in the presence of ozone.

The results obtained in this study are in accordance with those of Rodrigues-Silva et al [34,62], Palominos et al., [41] and Mansila et al. [63] who obtained more than $90 \%$ of Flumequine degradation according to the case. 
Insert Table 6, here

\subsection{Identification of reaction products and probable degradation pathways}

In order to identify the intermediate byproducts of Flumequine, a treated solution was analyzed after 30 minutes with Liquid chromatography coupled to tandem mass spectrometry (LCMS/MS). The structures shown in Fig. 9 below are the main photo-degradation by-products of Flumequine. It is obvious that a saturated ring opening has occurred, while the other two unsaturated rings remained stable. Furthermore, the aromatic ring remains remained stable within the degradation time of the molecule. Even after $2 \mathrm{~h}$ of photocatalytic degradation, the amount of compound (1) and (2) were still high in the solution. Another characteristic is that decarboxylation was one of the initial steps for the degradation pathway. This decarboxylation may happen because of the presence of $\mathrm{RCOO}-$ that reacts easily with the photo-generated holes $(\mathrm{h}+)$, thus producing a unit of $\mathrm{CO}_{2}$.

\section{Insert Fig. 9, here}

\subsection{Redox catalysis during the photocatalytic degradation}

The photo-generated of ROS radicals have been documented and characterized for most of their properties like: concentration, lifetimes, spectra and redox potentials by numerous workers $[29,64-67]$ reporting on the photocatalytic activity of $\mathrm{TiO}_{2}$ thin films. Light absorption in $\mathrm{TiO}_{2}$, induces the formation of $\mathrm{Ti}^{3+}$ prominent for O-vacancies and precluding $\mathrm{e}^{-} / \mathrm{h}^{+}$ recombination in $\mathrm{TiO}_{2}$.

Redox processes involving $\mathrm{Ti}^{4+} / \mathrm{Ti}^{3+}$ was seen to occur on the photocatalyst paper during the photo-degradation of the pollutant as shown in Figure $10 \mathrm{a} / \mathrm{b}$. At time zero, Figure 10 shows that $\mathrm{a} \mathrm{Ti}^{4+}$ peak at $458.2 \mathrm{eV}$ is slightly higher than the $\mathrm{Ti}^{3+}$ peak at $457.7 \mathrm{eV}$. Both oxidation states coexist on the $\mathrm{TiO}_{2}$-paper at time zero. After pollutant degradation, the $\mathrm{Ti}^{3+}$ peak increases to more than $80 \%$ of the XPS signal and the $\mathrm{Ti}^{4+}$ shows less than $20 \%$. This redox reaction on the $\mathrm{TiO}_{2}$ occurs concomitant to the pollutant degradation as shown in Figure 10 . 
The deconvolution of the O1s signal showed different oxygen bonds ( $\mathrm{Ti}-\mathrm{O}-\mathrm{H}, \mathrm{C}-\mathrm{O}, \mathrm{Ti}-\mathrm{O}-\mathrm{O})$ as shown in figure 11. A redox reaction for the Ti-O takes place, since this peak differs in position respect to the peak for the $\mathrm{TiO}_{2}$-based photocatalyst at $528.5 \mathrm{eV}$ as shown in figure 11 .

\section{Insert Fig. 10 \& 11, here}

\section{Conclusion}

In this study, the photocatalytic degradation of antibiotics (i.e. Flumequine and Clarithromycin) in water using a falling film reactor in combination with ozonation and/or hydrogen peroxide was developed. Critical parameters such as flow rate, light intensity and initial concentration were tested and show that they have a key role in the degradation rate. Mass transfer limitations were seen to occur at low concentration and reaction rate was enhanced at high flow rates. The results highlighted benefits of coupling photocatalysis with ozonation and hydrogen peroxide by showing their synergistic effects that has led to an enhancement of Flumequine degradation/mineralization rate. Therefore, this integrated process is very promising for use in wastewater treatment. Furthermore, hole, electron and ${ }^{\circ} \mathrm{OH}$ scavenger results show that the $\cdot \mathrm{OH}$ radical plays a crucial role in the degradation of Flumequine. It was also seen that the presence of $\mathrm{CCl}_{4}$ reduces the chance of recombination of ${ }^{\circ} \mathrm{H}$ and ${ }^{\circ} \mathrm{OH}$ which leads to an enhancement of removal efficiency of the tested antibiotic. Attention was also paid to identify the reaction products and the possible degradation pathways during Flumequine degradation. The photocatalytic activity was correlated with the redox catalysis occurring at the surface of the catalyst within the pollutant degradation time as shown by XPS results.

\section{References}

[1] J.A. Marcum, An introductory philosophy of medicine: Humanizing modern medicine, Springer Science \& Business Media, 2008.

[2] C.L. Ventola, The Antibiotic Resistance Crisis: Part 1: Causes and Threats, Pharm. Ther. 40 (2015) 277-283. http://www.ncbi.nlm.nih.gov/pmc/articles/PMC4378521/. 
[3] E.K. Silbergeld, J. Graham, L.B. Price, Industrial Food Animal Production, Antimicrobial Resistance, and Human Health, Annu. Rev. Public Health. 29 (2008) 151-169.

doi:10.1146/annurev.publhealth.29.020907.090904.

[4] J.-W. Kwon, K.L. Armbrust, Laboratory persistence and fate of fluoxetine in aquatic environments, Environ. Toxicol. Chem. 25 (2006) 2561-2568. doi:10.1897/05-613R.1.

[5] B. Petrie, R. Barden, B. Kasprzyk-hordern, A review on emerging contaminants in wastewaters and the environment : Current knowledge, understudied areas and recommendations for future monitoring, Water Res. 72 (2014) 3-27. doi:10.1016/j.watres.2014.08.053.

[6] K. Kümmerer, Pharmaceuticals in the Environment, Annu. Rev. Environ. Resour. 35 (2010) 5775. doi:10.1146/annurev-environ-052809-161223.

[7] G. Lofrano, R. Pedrazzani, G.L. and M. Carotenuto, Advanced Oxidation Processes for Antibiotics Removal: A Review, Curr. Org. Chem. 21 (2017) 1054-1067. doi:http://dx.doi.org/10.2174/1385272821666170103162813.

[8] M. Feng, L. Cizmas, Z. Wang, V.K. Sharma, Activation of ferrate ( VI ) by ammonia in oxidation of flumequine : Kinetics, transformation products , and antibacterial activity assessment, Chem. Eng. J. 323 (2017) 584-591. doi:10.1016/j.cej.2017.04.123.

[9] F. Tamtam, F. Mercier, B. Le Bot, J. Eurin, Q. Tuc Dinh, M. Clément, et al., Occurrence and fate of antibiotics in the Seine River in various hydrological conditions, Sci. Total Environ. 393 (n.d.) 84-95. doi:http://dx.doi.org/10.1016/j.scitotenv.2007.12.009.

[10] Z. Ye, H.S. Weinberg, M.T. Meyer, Trace Analysis of Trimethoprim and Sulfonamide, Macrolide, Quinolone, and Tetracycline Antibiotics in Chlorinated Drinking Water Using Liquid Chromatography Electrospray Tandem Mass Spectrometry, Anal. Chem. 79 (2007) 1135-1144. doi:10.1021/ac060972a.

[11] O.J. Pozo, C. Guerrero, J. V Sancho, M. Ibáñez, E. Pitarch, E. Hogendoorn, et al., Efficient approach for the reliable quantification and confirmation of antibiotics in water using on-line solid-phase extraction liquid chromatography/tandem mass spectrometry, J. Chromatogr. A. 1103 (2006) 83-93. doi:http://dx.doi.org/10.1016/j.chroma.2005.10.073.

[12] E. Zuccato, S. Castiglioni, R. Bagnati, M. Melis, R. Fanelli, Source, occurrence and fate of antibiotics in the Italian aquatic environment, J. Hazard. Mater. 179 (2010) 1042-1048. doi:http://dx.doi.org/10.1016/j.jhazmat.2010.03.110.

[13] N. Collado, S. Rodriguez-Mozaz, M. Gros, A. Rubirola, D. Barceló, J. Comas, et al., Pharmaceuticals occurrence in a WWTP with significant industrial contribution and its input into the river system, Environ. Pollut. 185 (2014) 202-212. doi:http://dx.doi.org/10.1016/j.envpol.2013.10.040.

[14] P. Verlicchi, M. Al Aukidy, A. Jelic, M. Petrović, D. Barceló, Comparison of measured and predicted concentrations of selected pharmaceuticals in wastewater and surface water: A case study of a catchment area in the Po Valley (Italy), Sci. Total Environ. 470 (2014) 844-854. doi:http://dx.doi.org/10.1016/j.scitotenv.2013.10.026. 
[15] R. López-Serna, S. Pérez, A. Ginebreda, M. Petrović, D. Barceló, Fully automated determination of 74 pharmaceuticals in environmental and waste waters by online solid phase extraction-liquid chromatography-electrospray-tandem mass spectrometry, Talanta. 83 (2010) 410-424. doi:http://dx.doi.org/10.1016/j.talanta.2010.09.046.

[16] J. Siemens, G. Huschek, C. Siebe, M. Kaupenjohann, Concentrations and mobility of human pharmaceuticals in the world's largest wastewater irrigation system, Mexico City-Mezquital Valley, Water Res. 42 (2008) 2124-2134. doi:10.1016/j.watres.2007.11.019.

[17] R.H. Lindberg, P. Wennberg, M.I. Johansson, M. Tysklind, B.A. V Andersson, Screening of human antibiotic substances and determination of weekly mass flows in five sewage treatment plants in Sweden, Environ. Sci. Technol. 39 (2005) 3421-3429.

[18] M. Carballa, F. Omil, J.M. Lema, M. Llompart, C. Garcia, I. Rodriguez, et al., Behaviour of pharmaceuticals and personal care products in a sewage treatment plant of northwest Spain, Water Sci. Technol. 52 (2005) 29-35.

[19] F. Yu, Y. Li, S. Han, J. Ma, Adsorptive removal of antibiotics from aqueous solution using carbon materials, Chemosphere. 153 (2016) 365-385.

[20] K. Zare, V.K. Gupta, O. Moradi, A.S.H. Makhlouf, M. Sillanpää, M.N. Nadagouda, et al., A comparative study on the basis of adsorption capacity between CNTs and activated carbon as adsorbents for removal of noxious synthetic dyes: a review, J. Nanostructure Chem. 5 (2015) 227-236. doi:10.1007/s40097-015-0158-x.

[21] R. Daghrir, P. Drogui, D. Robert, Photoelectrocatalytic technologies for environmental applications, J. Photochem. Photobiol. A Chem. 238 (2012) 41-52.

doi:http://dx.doi.org/10.1016/j.jphotochem.2012.04.009.

[22] V. Homem, L. Santos, Degradation and removal methods of antibiotics from aqueous matrices - A review, J. Environ. Manage. 92 (2011) 2304-2347. doi:http://dx.doi.org/10.1016/j.jenvman.2011.05.023.

[23] Commission Implementing Decision, EUR Lex European Union Law, 2015 (2015) 40-42. http://data.europa.eu/eli/dec_impl/2015/495/oj (accessed July 27, 2017).

[24] M.N. Chong, B. Jin, C.W.K. Chow, C. Saint, Recent developments in photocatalytic water treatment technology: A review, Water Res. 44 (2010) 2997-3027. doi:http://dx.doi.org/10.1016/j.watres.2010.02.039.

[25] A. A. Assadi, J. Palau, A. Bouzaza, D. Wolbert: A continuous air reactor for photocatalytic degradation of Isovaleraldehyde: Effect of different operating parameters and Chemical degradation pathway, Chemical Engineering Research and Design, 91 (2013) 1307-1316..

[26] H. De Lasa, B. Serrano-Rosales, Advances in Chemical Engineering: Photocatalytic Technologies, Academic Press, 2009.

[27] R.P. Hesketh, M.A.A. Abraham, Reaction engineering for pollution prevention, Elsevier, 2000.

[28] N. Serpone, KInetlc Studies In Heterogeneous Photocatalysis . 1. Photocatalytic Degradatlon of Matrix, (2015) 5726-5731. 
[29] A.A. Assadi, A. Bouzaza, D. Wolbert, Photocatalytic oxidation of trimethylamine and isovaleraldehyde in an annular reactor: Influence of the mass transfer and the relative humidity, J. Photochem. Photobiol. A Chem. 236 (2012) 61-69.

doi:https://doi.org/10.1016/j.jphotochem.2012.03.020.

[30] F.J. Beltran, A. Aguinaco, J.F. García-Araya, A. Oropesa, Ozone and photocatalytic processes to remove the antibiotic sulfamethoxazole from water, Water Res. 42 (2008) 3799-3808.

[31] K. Ikehata, N. Jodeiri Naghashkar, M. Gamal El-Din, Degradation of Aqueous Pharmaceuticals by Ozonation and Advanced Oxidation Processes: A Review, Ozone Sci. Eng. 28 (2006) 353414. doi:10.1080/01919510600985937.

[32] M. Mehrjouei, S. Müller, D. Möller, A review on photocatalytic ozonation used for the treatment of water and wastewater, Chem. Eng. J. 263 (2015) 209-219. doi:10.1016/j.cej.2014.10.112.

[33] C. Rodrigues-silva, M. Guedes, S. Rath, J. Roberto, Degradation of flumequine by the Fenton and photo-Fenton processes : Evaluation of residual antimicrobial activity, Sci. Total Environ. 445-446 (2013) 337-346. doi:10.1016/j.scitotenv.2012.12.079.

[34] C. Rodrigues, M.G. Maniero, S. Rath, J.R. Guimarães, Antibacterial Activity Inhibition after the Degradation of Flumequine by UV / H 202 Abstract :, 14 (2011) 1-9.

[35] M. Feng, L. Yan, X. Zhang, P. Sun, S. Yang, L. Wang, et al., Fast removal of the antibiotic flumequine from aqueous solution by ozonation: Influencing factors, reaction pathways, and toxicity evaluation, Sci. Total Environ. 541 (2016) 167-175. doi:10.1016/j.scitotenv.2015.09.048.

[36] M. Feng, R. Qu, X. Zhang, P. Sun, Y. Sui, L. Wang, et al., Degradation of flumequine in aqueous solution by persulfate activated with common methods and polyhydroquinone-coated magnetite / multi-walled carbon nanotubes catalysts, Water Res. 85 (2015) 1-10. doi:10.1016/j.watres.2015.08.011.

[37] C. Rodrigues-Silva, M.G. Maniero, S. Rath, J.R. Guimarães, Degradation of flumequine by photocatalysis and evaluation of antimicrobial activity, Chem. Eng. J. 224 (2013) 46-52. doi:http://dx.doi.org/10.1016/j.cej.2012.11.002.

[38] J. Nieto, J. Freer, D. Contreras, R.J. Candal, E.E. Sileo, H.D. Mansilla, Photocatalyzed degradation of flumequine by doped TiO 2 and simulated solar light, 155 (2008) 45-50. doi:10.1016/j.jhazmat.2007.11.026.

[39] N. Miranda-garcía, M.I. Maldonado, J.M. Coronado, S. Malato, Degradation study of 15 emerging contaminants at low concentration by immobilized TiO 2 in a pilot plant, 151 (2010) 107-113. doi:10.1016/j.cattod.2010.02.044.

[40] N. Miranda-garcía, S. Suárez, B. Sánchez, J.M. Coronado, S. Malato, M.I. Maldonado, Applied Catalysis B : Environmental Photocatalytic degradation of emerging contaminants in municipal wastewater treatment plant effluents using immobilized TiO 2 in a solar pilot plant, 103 (2011) 294-301. doi:10.1016/j.apcatb.2011.01.030. 
[41] R. Palominos, J. Freer, M.A. Mondaca, H.D. Mansilla, Evidence for hole participation during the photocatalytic oxidation of the antibiotic flumequine, 193 (2008) 139-145.

doi:10.1016/j.jphotochem.2007.06.017.

[42] M. Canle, M.I.F. Pérez, J.A. Santaballa, ScienceDirect Photocatalyzed degradation / abatement of endocrine disruptors, Curr. Opin. Green Sustain. Chem. 6 (2017) 101-138.

doi:10.1016/j.cogsc.2017.06.008.

[43] S. Babić, L. Ćurković, D. Ljubas, M. Čizmić, TiO2 assisted photocatalytic degradation of macrolide antibiotics, Curr. Opin. Green Sustain. Chem. 6 (2017) 34-41.

doi:http://dx.doi.org/10.1016/j.cogsc.2017.05.004.

[44] N.F.F. Moreira, J.M. Sousa, G. Macedo, A.R. Ribeiro, L. Barreiros, M. Pedrosa, et al., Photocatalytic ozonation of urban wastewater and surface water using immobilized TiO2 with LEDs: Micropollutants, antibiotic resistance genes and estrogenic activity, Water Res. 94 (2016) 10-22. doi:http://dx.doi.org/10.1016/j.watres.2016.02.003.

[45] L. Prieto-Rodriguez, S. Miralles-Cuevas, I. Oller, A. Agüera, G.L. Puma, S. Malato, Treatment of emerging contaminants in wastewater treatment plants (WWTP) effluents by solar photocatalysis using low TiO2 concentrations, J. Hazard. Mater. 211 (2012) 131-137. doi:http://dx.doi.org/10.1016/j.jhazmat.2011.09.008.

[46] A. Bernabeu, R.F. Vercher, L. Santos-Juanes, P.J. Simón, C. Lardín, M.A. Martínez, et al., Solar photocatalysis as a tertiary treatment to remove emerging pollutants from wastewater treatment plant effluents, Catal. Today. 161 (2011) 235-240. doi:http://dx.doi.org/10.1016/j.cattod.2010.09.025.

[47] S. Yahiat, F. Fourcade, S. Brosillon, A. Amrane, International Biodeterioration \& Biodegradation Removal of antibiotics by an integrated process coupling photocatalysis and biological treatment e Case of tetracycline and tylosin, Int. Biodeterior. Biodegradation. 65 (2011) 997-1003. doi:10.1016/j.ibiod.2011.07.009.

[48] L. Lhomme, S. Brosillon, D. Wolbert, Photocatalytic degradation of pesticides in pure water and a commercial agricultural solution on TiO 2 coated media, 70 (2008) 381-386. doi:10.1016/j.chemosphere.2007.07.004.

[49] B. Stephan, L. Ludovic, W. Dominique, Modelling of a falling thin film deposited photocatalytic step reactor for water purification: Pesticide treatment, Chem. Eng. J. 169 (2011) 216-225.

[50] A.A. Assadi, A. Bouzaza, D. Wolbert, Study of synergetic effect by surface discharge plasma/TiO combination for indoor air treatment: sequential and continuous configurations at pilot scale, Journal of Photochemistry and Photobiology A: Chemistry: 310 (2015)148-154

[51] G. Malekshoar, A.K. Ray, In-situ grown molybdenum sulfide on $\mathrm{TiO}_{2}$ for dye-sensitized solar photocatalytic hydrogen generation, Chem. Eng. Sci. 152 (2016) 35-44.

[52] A. Brucato, A.E. Cassano, F. Grisafi, G. Montante, L. Rizzuti, G. Vella, Estimating radiant fields in flat heterogeneous photoreactors by the six-flux model, AIChE J. 52 (2006) 3882-3890. doi:10.1002/aic.10984. 
[53] B. Toepfer, A. Gora, G. Li Puma, Photocatalytic oxidation of multicomponent solutions of herbicides: Reaction kinetics analysis with explicit photon absorption effects, Appl. Catal. B Environ. 68 (2006) 171-180. doi:http://dx.doi.org/10.1016/j.apcatb.2006.06.020.

[54] B. Sheidaei, M.A. Behnajady, Efficiency of a Photoreactor Packed with Immobilized Titanium Dioxide Nanoparticles in the Removal of Acid Orange 7, Water Environ. Res. 88 (2016) 449457.

[55] X. Hao, H. Li, Z. Zhang, C. Fan, S. Liu, Y. Sun, Modeling and experimentation of a novel labyrinth bubble photoreactor for degradation of organic pollutant, Chem. Eng. Res. Des. 87 (2009) 1604-1611.

[56] A.A. Assadi, J. Palau, A. Bouzaza, D. Wolbert, Modeling of a continuous photocatalytic reactor for isovaleraldehyde oxidation: Effect of different operating parameters and chemical degradation pathway, Chem. Eng. Res. Des. 91 (2013) 1307-1316. doi:http://dx.doi.org/10.1016/j.cherd.2013.02.020.

[57] J. Herrmann, Active agents in heterogeneous photocatalysis: atomic oxygen species vs. $\mathrm{OH}$. radicals: related quantum yields, Helv. Chim. Acta. 84 (2001) 2731-2750.

[58] V. Despotovic, B. Abramovic, N. Finc, Mechanism of clomazone photocatalytic degradation : hydroxyl radical , electron and hole scavengers, (2015) 67-79. doi:10.1007/s11144-014-0814$z$.

[59] A. Shet, V. Shetty, Photocatalytic degradation of phenol using Ag core-TiO2 shell (Ag@ TiO2) nanoparticles under UV light irradiation, Environ. Sci. Pollut. Res. (2015) 1-10.

[60] Y. Nakabayashi, Y. Nosaka, OH radical formation at distinct faces of rutile TiO2 crystal in the procedure of photoelectrochemical water oxidation, J. Phys. Chem. C. 117 (2013) 2383223839.

[61] J. Wang, Y. Sun, J. Feng, L. Xin, J. Ma, Degradation of triclocarban in water by dielectric barrier discharge plasma combined with $\mathrm{TiO}_{2}$ /activated carbon fibers: Effect of operating parameters and byproducts identification, Chem. Eng. J. 300 (2016) 36-46.

doi:http://dx.doi.org/10.1016/j.cej.2016.04.041.

[62] C. Rodrigues-silva, M. Guedes, S. Rath, J. Roberto, Degradation of flumequine by photocatalysis and evaluation of antimicrobial activity, Chem. Eng. J. 224 (2013) 46-52. doi:10.1016/j.cej.2012.11.002.

[63] H.D. Mansilla, A. Mora, C. Pincheira, M.A. Mondaca, New photocatalytic reactor with TiO 2 coating on sintered glass cylinders, 76 (2007) 57-63. doi:10.1016/j.apcatb.2007.04.025.

[64] S. Rtimi, C. Pulgarin, R. Sanjines, J. Kiwi, Innovative semi-transparent nanocomposite films presenting photo-switchable behavior and leading to a reduction of the risk of infection under sunlight, RSC Adv. 3 (2013) 16345-16348. doi:10.1039/C3RA42762E.

[65] J. Nesic, S. Rtimi, D. Laub, G.M. Roglic, C. Pulgarin, J. Kiwi, New evidence for TiO2 uniform surfaces leading to complete bacterial reduction in the dark: Critical issues, Colloids And Surfaces B-Biointerfaces. 123 (2014) 593-599. doi:10.1016/j.colsurfb.2014.09.060. 
[66] A. FUJISHIMA, X. ZHANG, D. TRYK, TiO2 photocatalysis and related surface phenomena, Surf. Sci. Rep. 63 (2008) 515-582. doi:10.1016/j.surfrep.2008.10.001.

[67] M. Pelaez, N.T. Nolan, S.C. Pillai, M.K. Seery, P. Falaras, A.G. Kontos, et al., A review on the visible light active titanium dioxide photocatalysts for environmental applications, Appl. Catal. B Environ. 125 (2012) 331-349. doi:http://dx.doi.org/10.1016/j.apcatb.2012.05.036. 


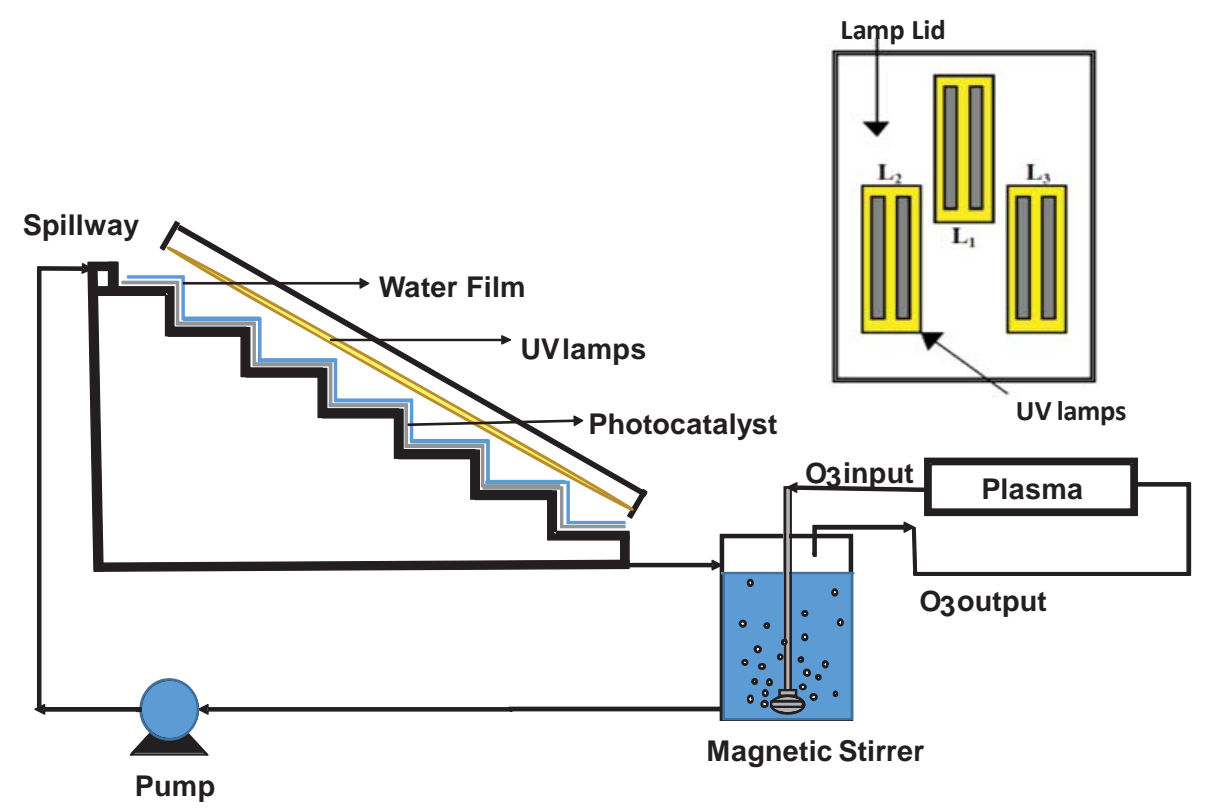

Fig 1. Scheme of the falling film photoreactor used during the course of this study.

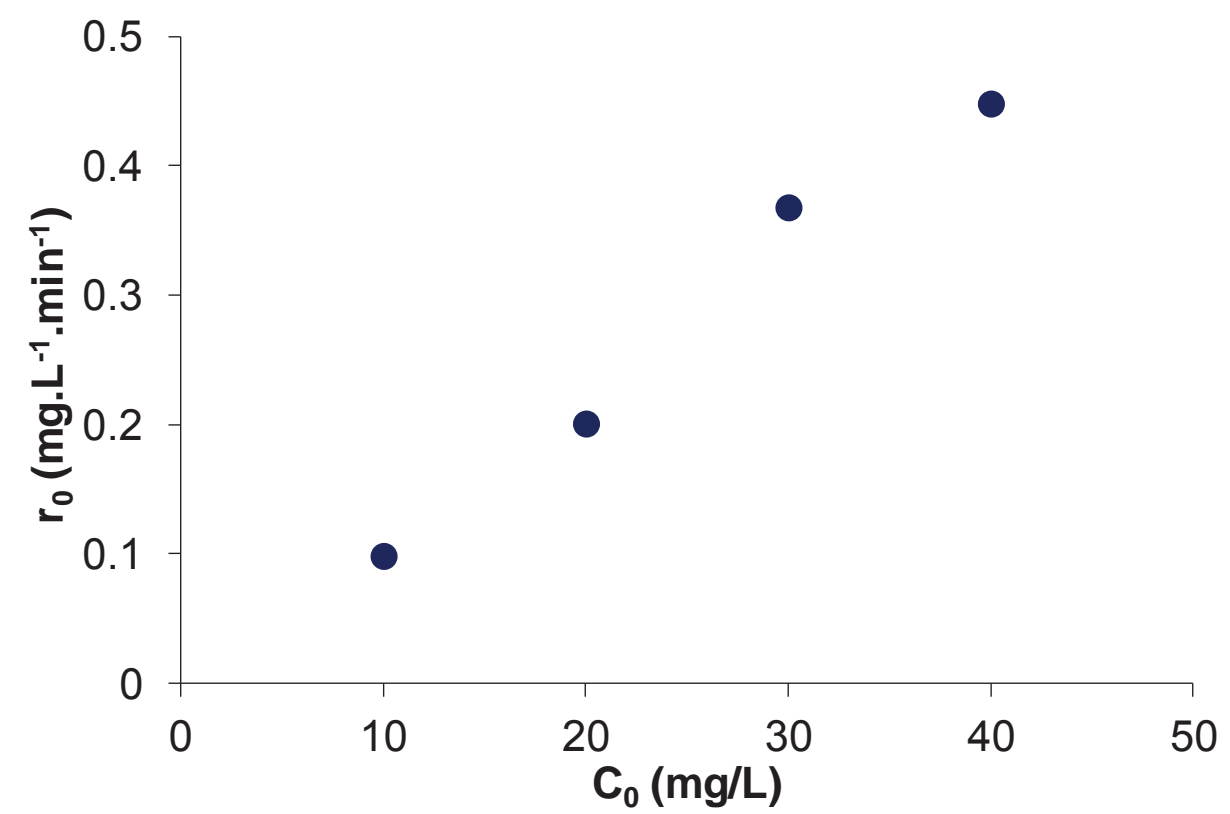

Fig 2. Effect of initial concentration of Flumequine on reaction rate $\left(\mathrm{UV} / \mathrm{TiO}{ }_{2}\right)$. Flowrate=77L/h, light intensity=38 W.m-2, initial concentrations= $10 \mathrm{mg} / \mathrm{L} ; 20 \mathrm{mg} / \mathrm{L} ; 30 \mathrm{mg} / \mathrm{L}$ and $40 \mathrm{mg} / \mathrm{L}$. 


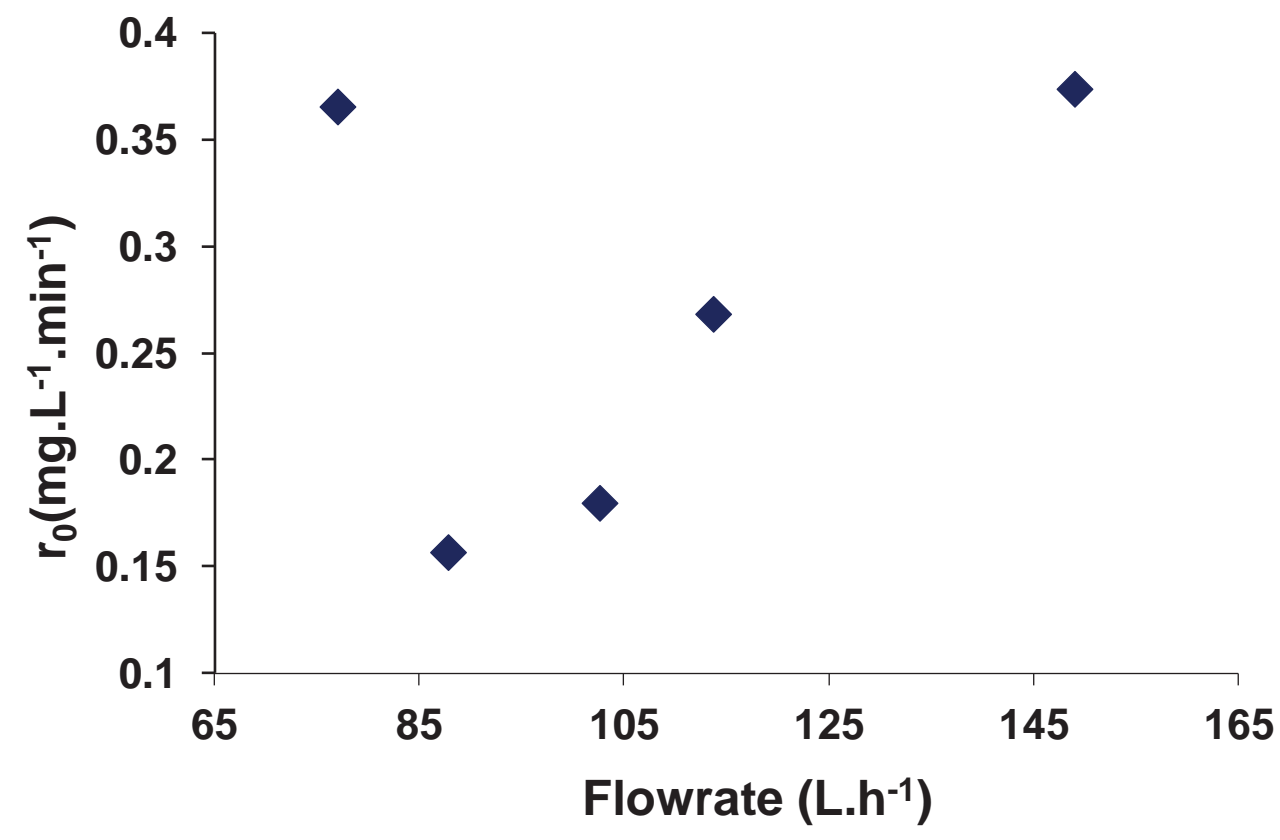

Fig. 3.Effect of the flowrate on the reaction rates (Flumequine degradation by UV/TiO 2 ). Light intensity $=38 \mathrm{~W} \cdot \mathrm{m}^{-2}$, initial concentration $=30 \mathrm{mg} / \mathrm{L}$

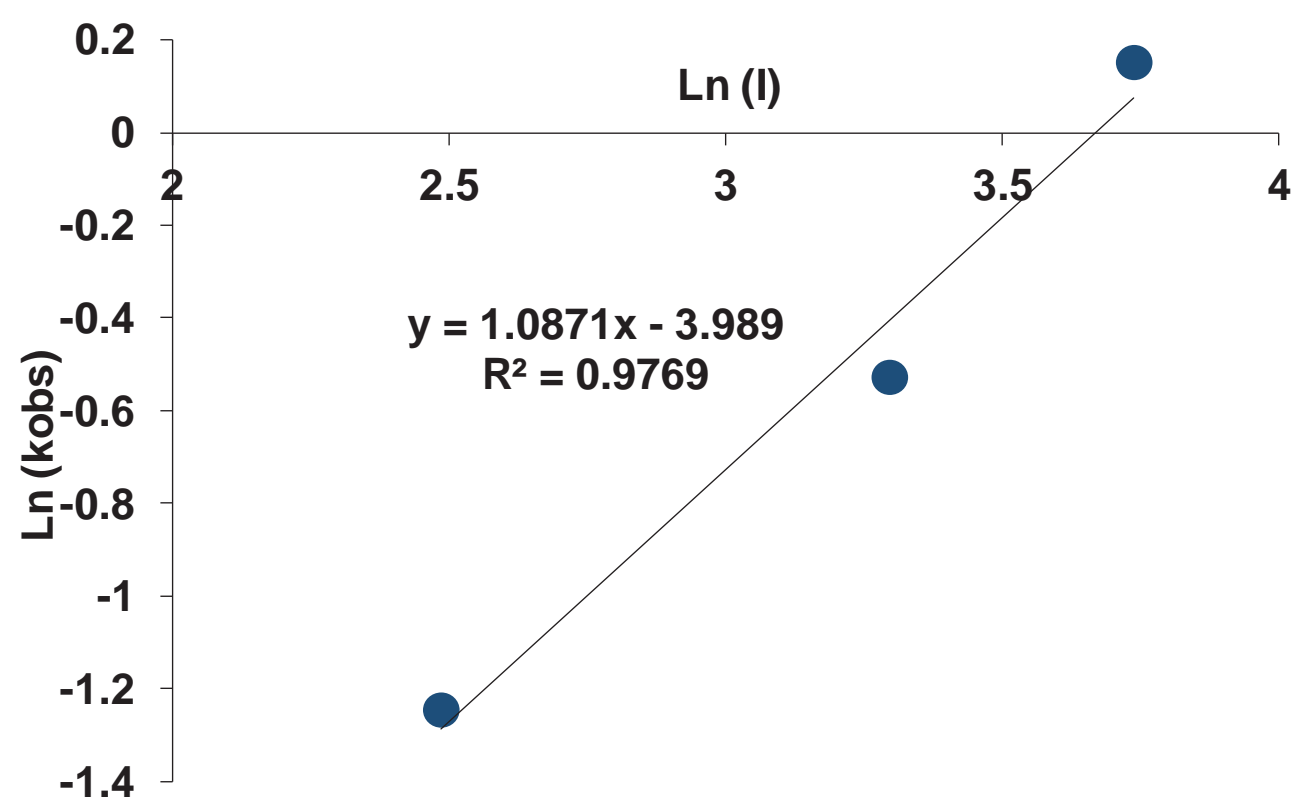

Fig. 4. The influence of the UV light intensity on Flumequine degradation rate by $\mathrm{UV}^{\mathrm{T}} \mathrm{TiO}{ }_{2}$.

Flowrate $=77 \mathrm{~L} / \mathrm{h}$., initial concentration $=30 \mathrm{mg} / \mathrm{L}$ 


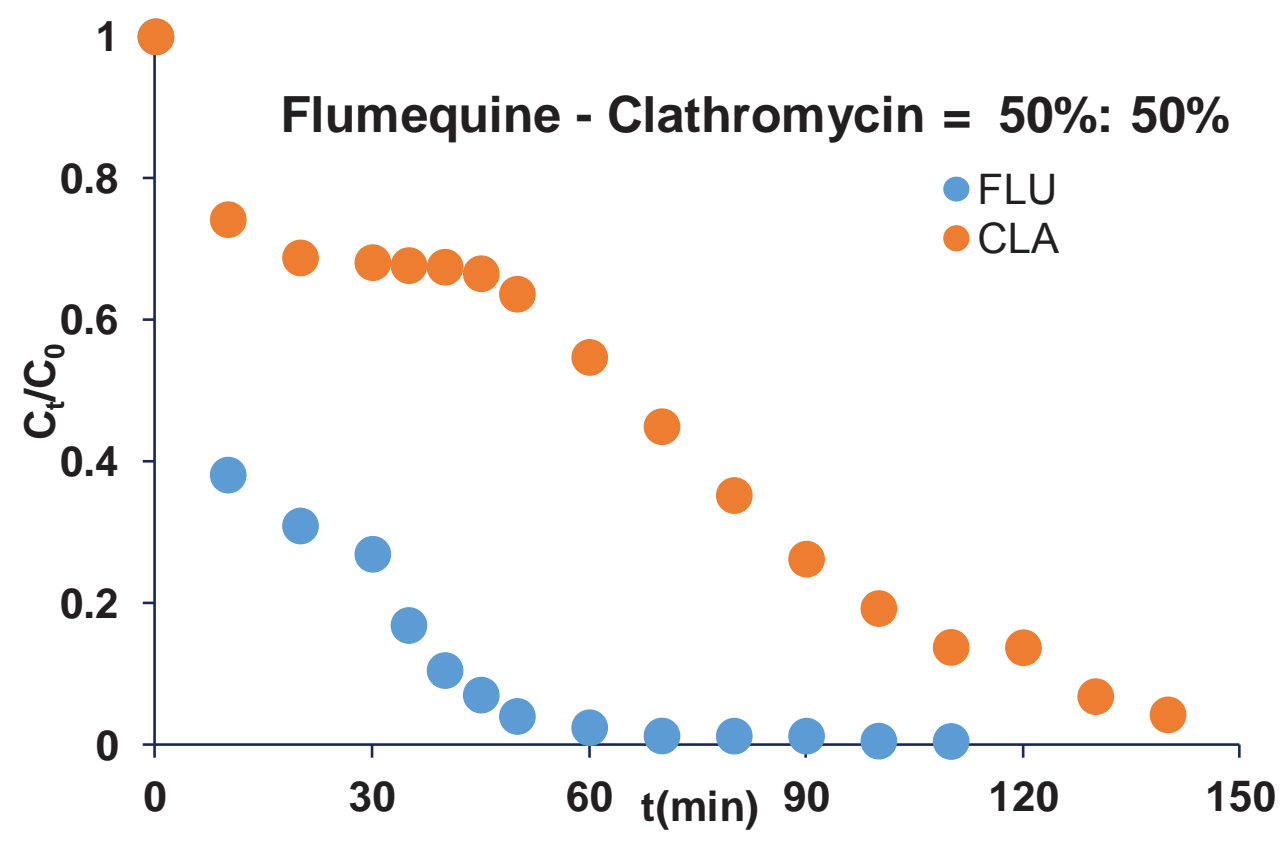

Fig. 5. Removal equimolar concentration of Flumequine (FLU) and Clarithromycin (CLA) via time. Flowrate $=77 \mathrm{~L} / \mathrm{h} .$, . Light intensity $=38 \mathrm{~W} . \mathrm{m}^{-2}$,

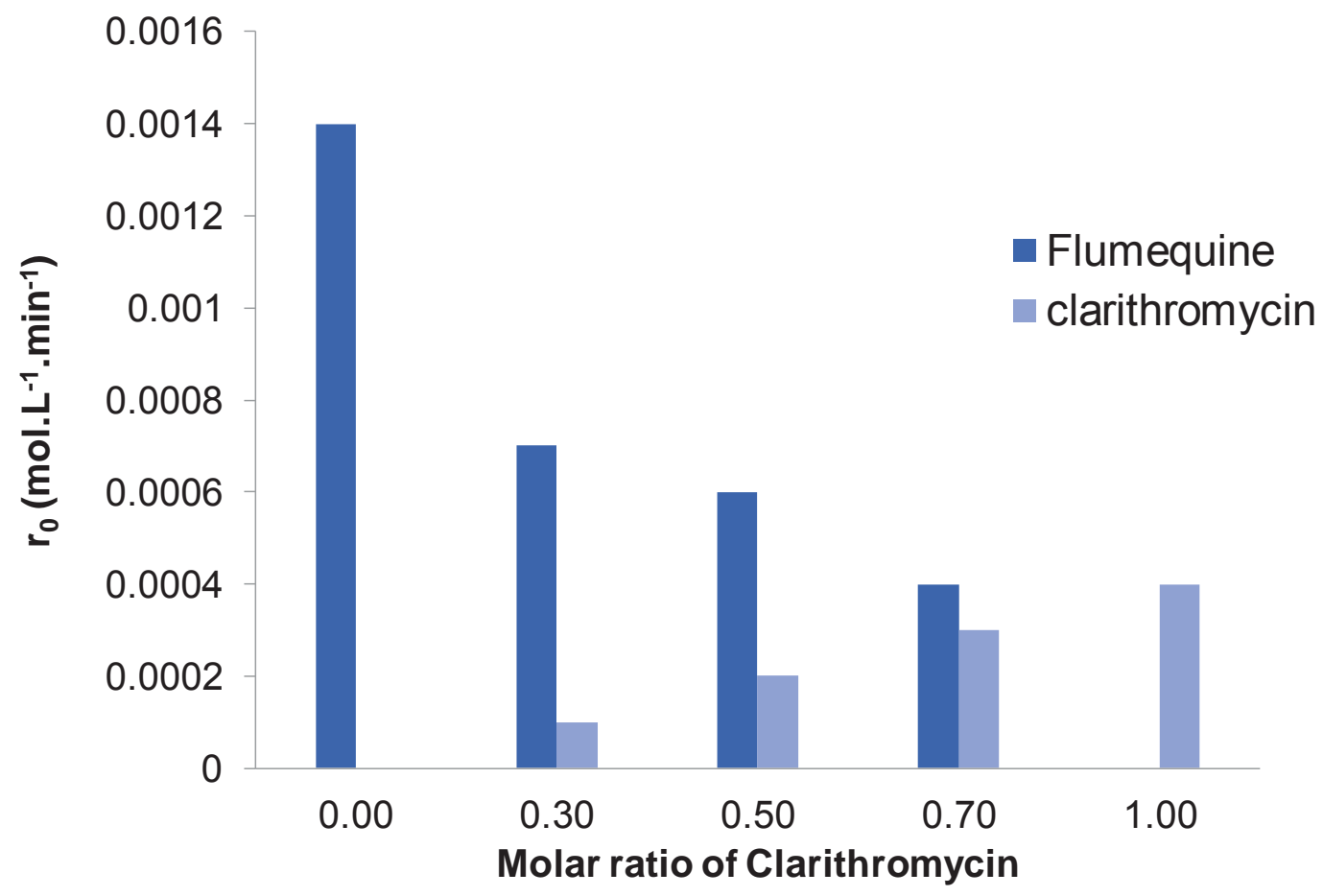

Fig. 6. The reaction rate in the case of mixture of Flumequine and Clarithromycin via time.

. Flowrate $=77 \mathrm{~L} / \mathrm{h}$., initial concentration $=30 \mathrm{mg} / \mathrm{L}$, Light intensity $=38 \mathrm{~W} \cdot \mathrm{m}^{-2}$, 


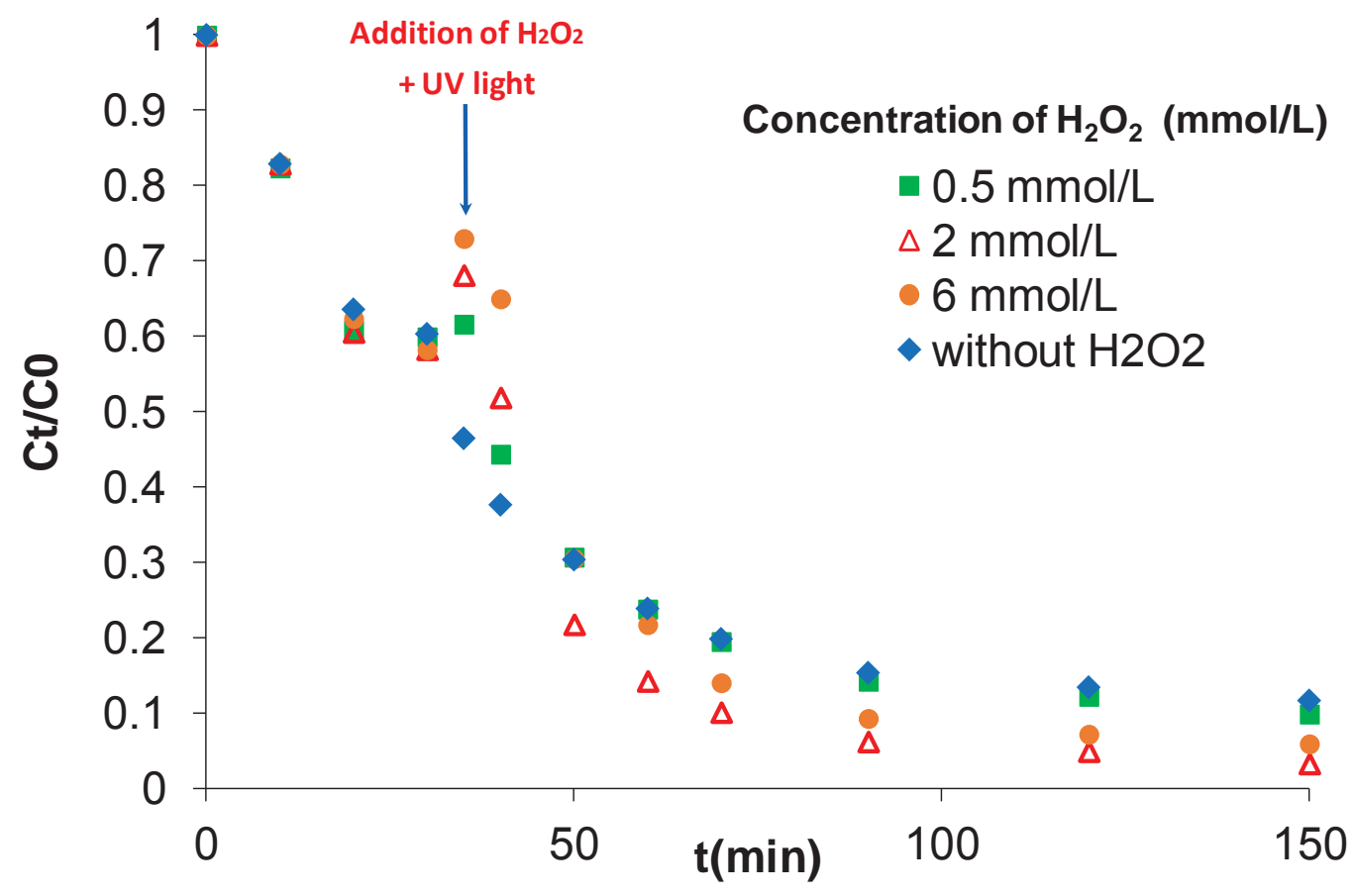

Fig. 7.Concentration of Flumequine in the $\mathrm{TIO}_{2} / \mathrm{UV} / \mathrm{H}_{2} \mathrm{O}_{2}$ system

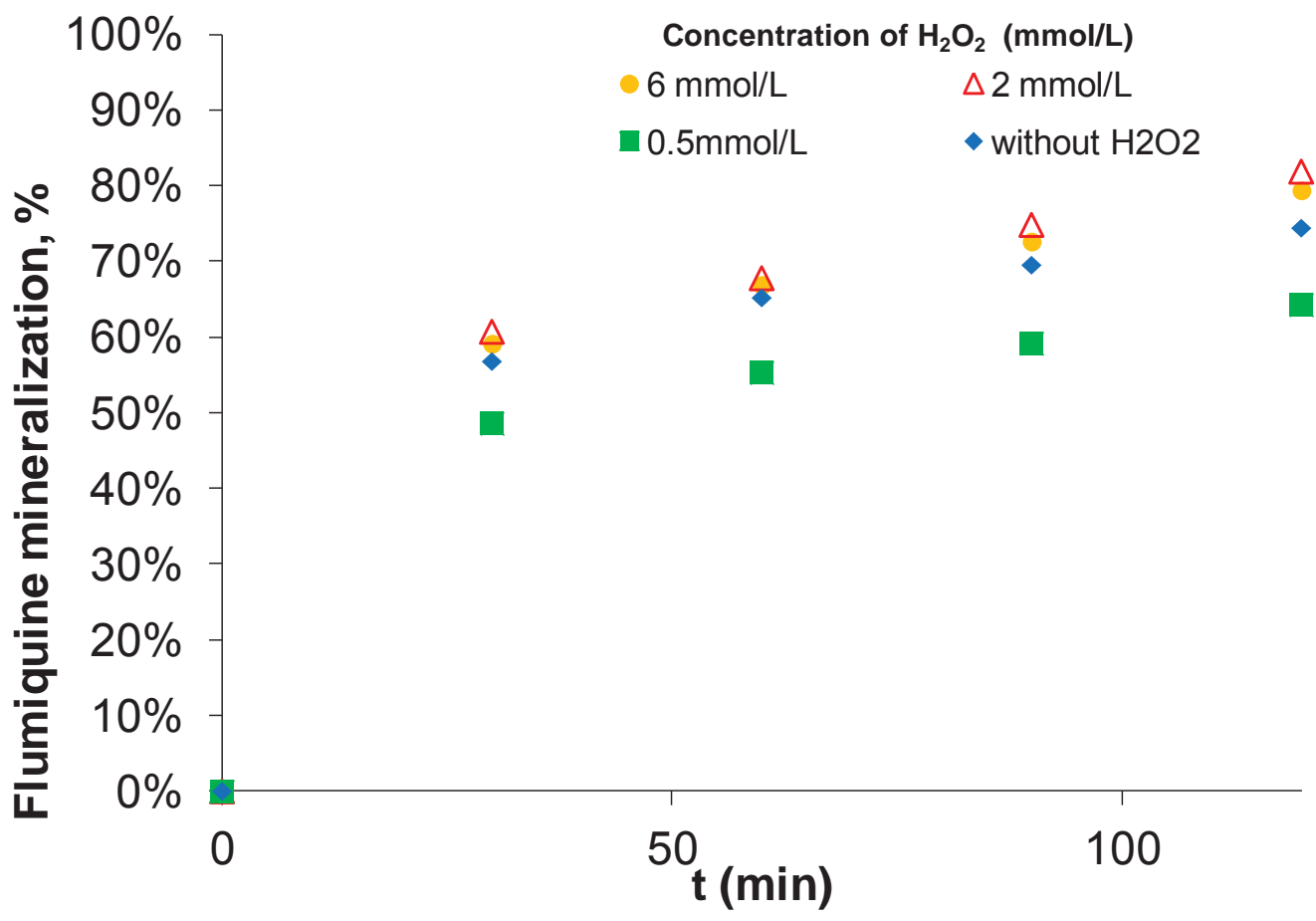

Fig. 8. Removal TOC of Flumequine in the $\mathrm{TIO}_{2} / \mathrm{H}_{2} \mathrm{O}_{2} / \mathrm{UV}$ system. .Flowrate=77L/h, . Light intensity $=38 \mathrm{~W} \cdot \mathrm{m}^{-2}$, Initial concentration $=30 \mathrm{mg} / \mathrm{L}$ 


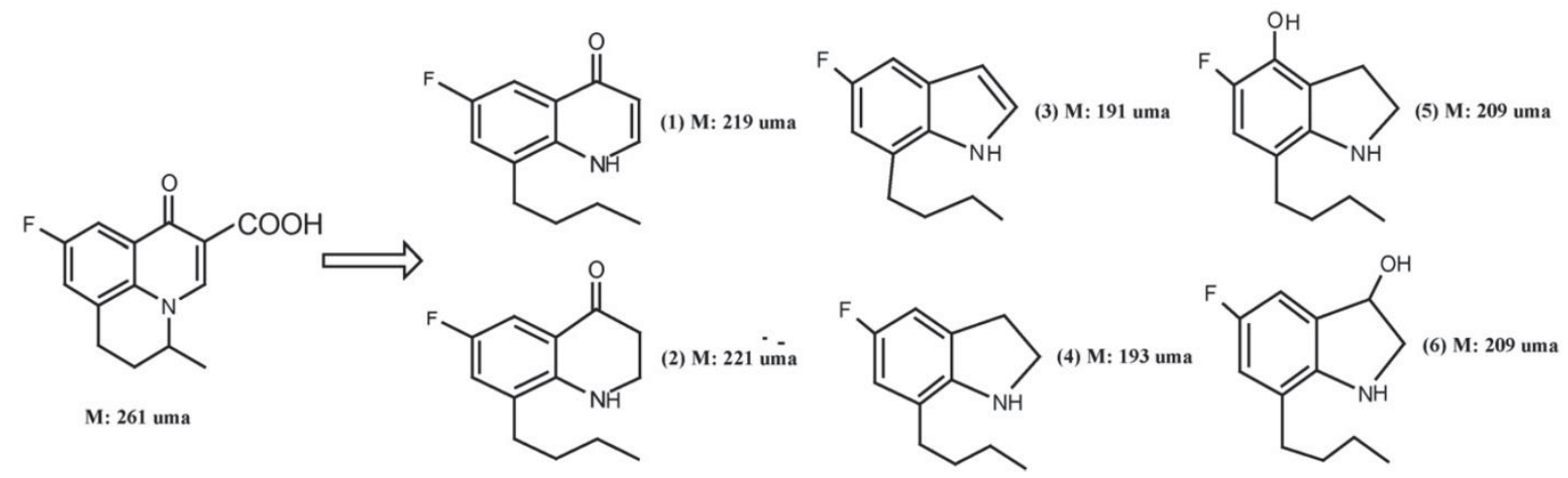

Fig 9. Structures of main by-products after $\mathbf{3 0}$ minutes UV irradiation of Flumequine solutions [41].

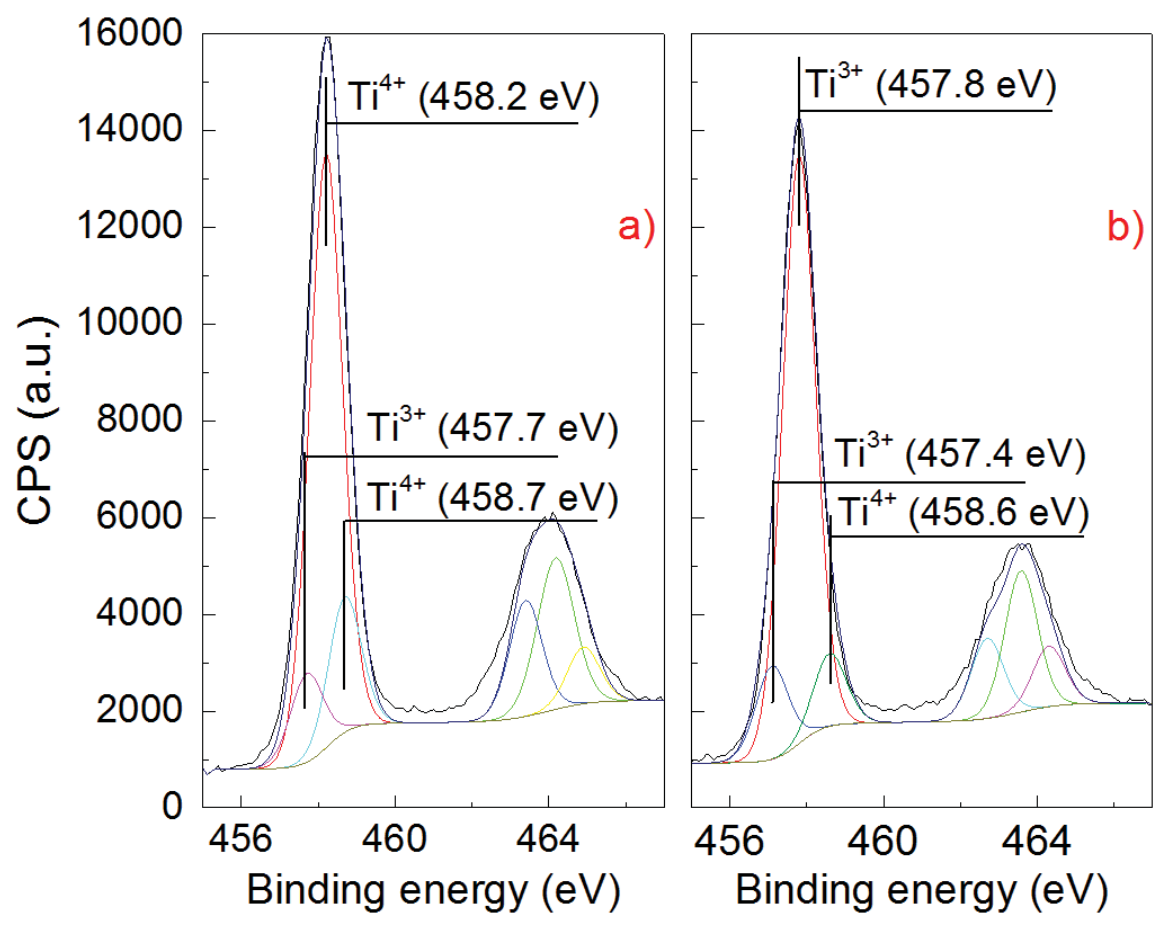

Fig 10. XPS deconvolution of Ti2p peaks: a) before and b) after UV degradation of Flumequine. 


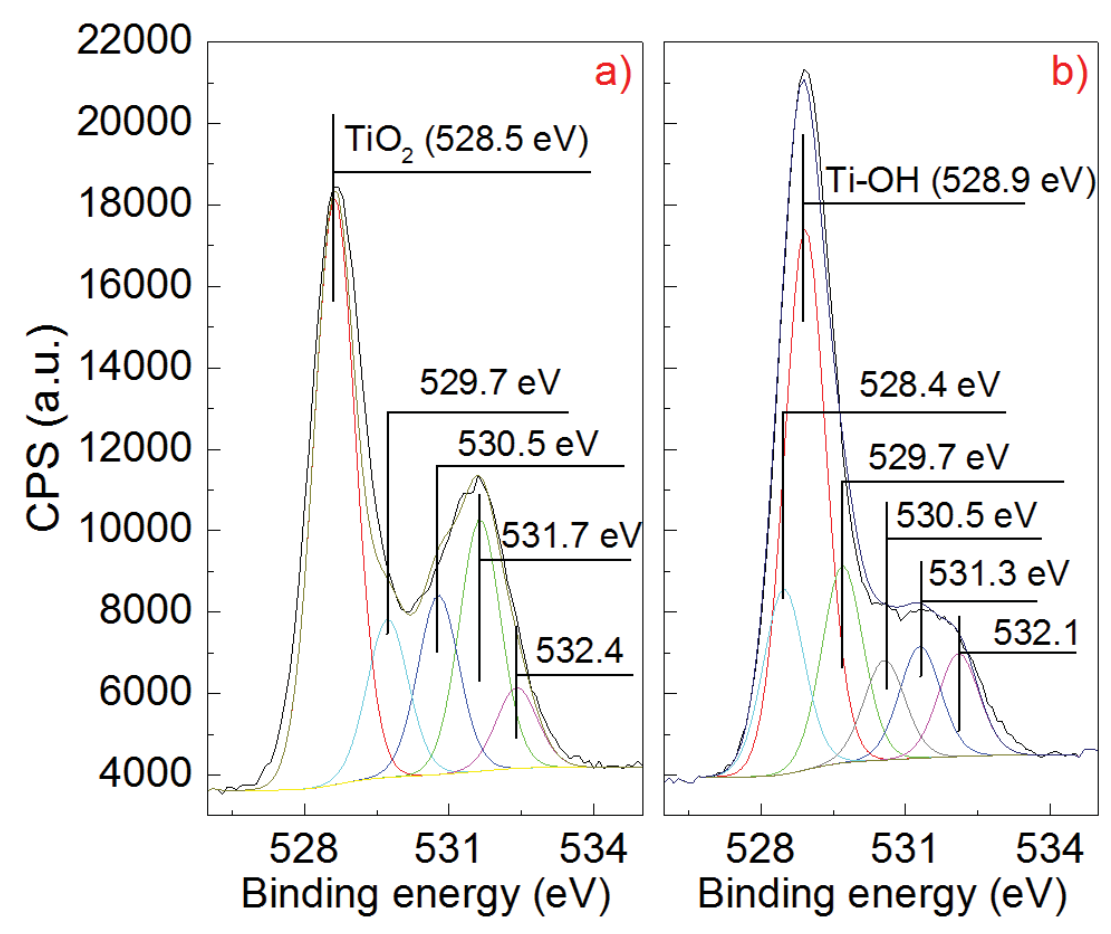

Fig 11. XPS deconvolution of O1s peaks: a) before and b) after UV degradation of Flumequine. 
Table 1. The values of $k$ in the different flow rates

\begin{tabular}{lccccc}
\hline Flowrate, $\mathbf{Q}$ & $77.0 \mathrm{~L} / \mathrm{h}$ & $87.8 \mathrm{~L} / \mathrm{h}$ & $102.6 \mathrm{~L} / \mathrm{h}$ & $113.7 \mathrm{~L} / \mathrm{h}$ & $149.0 \mathrm{~L} / \mathrm{h}$ \\
& & & & & \\
\hline $\mathbf{k}(\mathbf{m g} / \mathrm{L} . \min )$ & 1.165 & 0.335 & 0.405 & 0.691 & 1.177 \\
& & & & & \\
\hline
\end{tabular}

Table 2. The values of film thickness in the different flow rates

\begin{tabular}{llllll}
\hline Flowrate, Q & $77.0 \mathrm{~L} / \mathrm{h}$ & $87.8 \mathrm{~L} / \mathrm{h}$ & $102.6 \mathrm{~L} / \mathrm{h}$ & $113.7 \mathrm{~L} / \mathrm{h}$ & $149.0 \mathrm{~L} / \mathrm{h}$ \\
& & & & & \\
\hline film thickness(mm) & 0.907 & 0.990 & 1.099 & 1.177 & 1.409 \\
& & & & & \\
\hline
\end{tabular}

Table 3. The values of apparent kinetic constant at different UV intensity

$\begin{array}{llll}\text { UV intensity, I (W/m²) } & 12 & 27 & 42\end{array}$
$\mathrm{k}\left(\mathrm{mg} \cdot \mathrm{L}^{-1} \cdot \mathrm{min}^{-1}\right)$
0.288
0.590
1.164

Table 4. Tested scavengers, involved radical and reaction scheme [61]

\begin{tabular}{ccc}
\hline Scavengers & Involved radical & Reaction mechanism \\
\hline $\mathrm{CCl}_{4}$ & $\mathrm{H}^{\bullet}$ & $\mathrm{CCl}_{4}+\mathrm{H}^{\bullet} \rightarrow \cdot \mathrm{CCl}_{3}+\mathrm{HCl}$ \\
Iso-propanol & $\mathrm{OH}^{\bullet}$ & $\left(\mathrm{CH}_{3}\right)_{2} \mathrm{CHOH}+\mathrm{OH}^{\bullet} \rightarrow\left(\mathrm{CH}_{3}\right)_{2} \mathrm{COH}+\mathrm{H}_{2} \mathrm{O}$ \\
EDTA & $\mathrm{OH} \cdot$ & $\mathrm{EDTA}+\mathrm{OH}^{\bullet}$ \\
Without scavenger & $\mathrm{H}_{2} \mathrm{O} \stackrel{\mathrm{UV}}{\rightarrow} \mathrm{OH}^{\bullet}+\mathrm{H}^{\bullet}$ \\
\hline
\end{tabular}


Table.5 Removals efficiency and TOC (for different scavengers) after $\mathbf{3 0 0}$ min of reaction. Flowrate $=77 \mathrm{~L} / \mathrm{h}$, Light intensity $=38 \mathrm{~W} \cdot \mathrm{m}^{-2}$, initial concentration $=30 \mathrm{mg} / \mathrm{L}$

\begin{tabular}{|c|c|c|}
\hline Scanvengers & $\begin{array}{c}\text { Degradation after 300min of } \\
\text { reaction }\end{array}$ & $\begin{array}{c}\text { Minerilization after 300min of } \\
\text { reaction }\end{array}$ \\
\hline without scavenger & $75 \%$ & $40 \%$ \\
\hline EDTA & $93.19 \%$ & $84 \%$ \\
\hline isopropanol & $95 \%$ & $96 \%$ \\
\hline $\mathrm{CCl}_{4}$ & $97 \%$ & $91 \%$ \\
\hline
\end{tabular}

Table 6: Degradation and mineralization efficiencies of Flumequine (\%) at 240 minutes in different systems. .Flowrate $=77 \mathrm{~L} / \mathrm{h}$.,. Light intensity $=38 \mathrm{~W} \cdot \mathrm{m}^{-2}$, Initial concentration $=30 \mathrm{mg} / \mathrm{L}$

\begin{tabular}{|c|c|c|}
\hline $\begin{array}{c}\text { Type of } \\
\text { Treatment }\end{array}$ & $\begin{array}{c}\text { Degradation after 240min of } \\
\text { reaction }\end{array}$ & $\begin{array}{c}\text { Minerilization after 240min of } \\
\text { reaction }\end{array}$ \\
\hline $\mathrm{UV} / \mathrm{O}_{3}$ & $40 \%$ & $10 \%$ \\
\hline $\mathrm{TiO}_{2} / \mathrm{O}_{3}$ & $52 \%$ & $42 \%$ \\
\hline $\mathrm{TiO}_{2} / \mathrm{UV}$ & $90 \%$ & $62 \%$ \\
\hline $\mathrm{TiO}_{2} / \mathrm{UV} / \mathrm{O}_{3}$ & $92 \%$ & $68 \%$ \\
\hline $\mathrm{TiO}_{2} / \mathrm{UV} / \mathrm{H}_{2} \mathrm{O}_{2}$ & $93 \%$ & $72 \%$ \\
\hline $\mathrm{TiO}_{2} / \mathrm{UV} / \mathrm{H}_{2} \mathrm{O}_{2} / \mathrm{O}_{3}$ & $94 \%$ & $76 \%$ \\
\hline
\end{tabular}


List of tables: 